\title{
Sites and Mechanisms of Localization of
}

\section{Technetium-99m Phosphorus Radiopharmaceuticals in Acute Myocardial Infarcts and other Tissues}

\author{
L. Maximilian Buja, Andrew J. Tofe, Padmakar V. Kulkarni, Amal Mukherjee, \\ Robert W. Parkey, Marion D. Francis, Frederick J. Bonte, and James T. Willerson
}

From the Departments of Pathology, Radiology, and Internal Medicine, Southwestern Medical School, The University of Texas Health Science Center at Dallas, Dallas, Texas 75235 and

The Miami Valley Laboratories, The Procter and Gamble Company, Cincinnati, Ohio 4523.9

\begin{abstract}
A B S T R A C T This study was performed to elucidate the localization at the cellular level of technetium-99m phosphorus $\left.{ }^{99 \mathrm{~m}} \mathrm{Tc}-\mathrm{P}\right)$ radiopharmaceuticals in acute myocardial infarcts and the mechanisms responsible for ${ }^{99 \mathrm{~m}} \mathrm{Tc}-\mathrm{P}$ uptake in acute myocardial infarcts and other tissues. In 20 dogs with proximal left anterior descending coronary arterial ligation for 1-3 days, elevated calcium levels were measured at all sites of increased ${ }^{99 \mathrm{~m}} \mathrm{Tc}-\mathrm{P}$ uptake (acute myocardial infarcts, necrotic thoracotomy muscle, lactating breast, and normal bone); however, a consistent linear relationship between ${ }^{99 \mathrm{~m}} \mathrm{~T}$ c-P and calcium levels was not observed. A strong correlation $(r=0.95$ and $0.99, n=2$ dogs $)$ was demonstrated between levels of ${ }^{3} \mathrm{H}$-diphosphonate and ${ }^{99 \mathrm{~m}} \mathrm{Tc}-\mathrm{P}$ in infarcted myocardium. Autoradiographic studies with ${ }^{3} \mathrm{H}$-diphosphonate revealed extensive labeling in the infarct periphery which contained necrotic muscle cells with features of severe calcium overloading, including widespread hypercontraction as well as more selective formation of mitochondrial calcific deposits. Autoradiography also demonstrated labeling of a small population of damaged border zone muscle cells which exhibited prominent accumulation of lipid droplets and focal, early mitochondrial calcification. Cell fractionation
\end{abstract}

Some of the data from this study has been presented and published in abstract form in 1976 (Fed. Proc. 34: 230.; J. Nucl. Med. 17: 523.; and Circulation. 54[Suppl. II]: II-219).

Dr. Willerson is an Established Investigator of the American Heart Association.

Received for mublication 8 February 1977 and in revised form 22 April 1977. studies revealed major localization of both ${ }^{99 \mathrm{~m}} \mathrm{Tc}-\mathrm{P}$ and calcium in the soluble supernate and membranedebris fractions of infarcted myocardium and less than $2 \%$ of total ${ }^{99 m} \mathrm{Tc}-\mathrm{P}$ and calcium in the mitochondrial fractions; however, electron microscopic examination showed that mitochondria with calcific deposits were not preserved in the mitochondrial fractions. In vitro studies evaluating the role of serum protein binding on tissue uptake of ${ }^{99} \mathrm{~m} \mathrm{Tc}-\mathrm{P}$ agents demonstrated that, in spite of significant complexing with serum proteins, serum ${ }^{99 \mathrm{~m}} \mathrm{Tc}-\mathrm{P}$ activity retained the ability to adsorb to calcium hydroxyapatite and amorphous calcium phosphate. In vivo studies showed that concentration of human serum albumin (labeled with iodine-131) in infarcted myocardium reached a maximum of only 3.8 times normal after a circulation time of $96 \mathrm{~h}$, whereas ${ }^{99 m}$ Tc-P uptake was at least 10 times normal after a circulation time as short as $1 \mathrm{~h}$. It is concluded that:

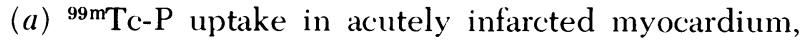
and possibly other types of soft tissue damage, is limited to necrotic and severely injured cells; $(b)$ concentration of ${ }^{99 \mathrm{~m}} \mathrm{Tc}-\mathrm{P}$ results from selective adsorption of ${ }^{99 \mathrm{~m}} \mathrm{Tc}-\mathrm{P}$ with various forms of tissue calcium stores, including amorphous calcium phosphate, crystalline hydroxyapatite, and calcium complexed with myofibrils and other macromolecules, possibly supplemented by calcium-independent complexing with organic macromolecules; and $(c)$ lack of a linear relationship between ${ }^{99 m} \mathrm{Tc}-\mathrm{P}$ and tissue calcium levels mainly results from local differences in composition and physicochemical properties of tissue calcium stores and from local variations in levels of blood flow for delivery of ${ }^{99 \mathrm{~m} T \mathrm{C}-\mathrm{P}}$ agents. 


\section{INTRODUCTION}

Myocardial scintigraphy with technetium-99m-labeled, phosphorus-based radiopharmaceuticals $\left({ }^{99} \mathrm{~m} \mathrm{Tc}-\mathrm{P}\right)^{1}$ has been shown to be an accurate noninvasive test for the diagnosis of acute myocardial infarction (1). Bonte and associates first showed that the ${ }^{99 \mathrm{~m}} \mathrm{Tc}-\mathrm{P}$ bone scanning agents concentrate in areas of acute myocardial infarction, and suggested that this phenomenon was related to labeling of calcium deposits in the infarcts (2). Our previous experimental studies have demonstrated that a positive ${ }^{99 \mathrm{~m} T c-P}$ myocardial scintigram results from selective concentration of the agent in areas with partial to homogeneous myocardial necrosis, multifocal muscle cell calcification, and residual blood flow (3-6). These findings were interpreted as supporting the proposed role of tissue calcification in concentration of the agent, but as not excluding the possibility of other mechanisms (3-6). Other reports (7-16) have confirmed the dependence of ${ }^{99 \mathrm{~m} T c-P}$ concentration on the presence of myocardial necrosis, and the importance of blood flow for modulating the level of ${ }^{99 m} \mathrm{Tc}-\mathrm{P}$ uptake. Previous studies from our own and other laboratories, however, have not resolved certain important questions regarding ${ }^{99 \mathrm{~m} T c-P}$ uptake after myocardial injury. The previous studies have not precisely defined whether ${ }^{99 \mathrm{~m} T c-P}$ uptake is limited to severely damaged or frankly necrotic cells or whether ${ }^{99 \mathrm{~m}} \mathrm{Tc}-\mathrm{P}$ uptake also can occur in cells with mild, clearly reversible injury. In addition, mechanisms of tissue concentration of ${ }^{99 \mathrm{~m}} \mathrm{Tc}-\mathrm{P}$ agents have not been definitively characterized. Although Reimer and associates (13) have confirmed an association between calcium accumulation and ${ }^{99 m} \mathrm{Tc}-\mathrm{P}$ uptake in ischemic myocardium, other workers have suggested a less important role for complexing with calcium deposits than originally proposed (15-19). In particular, Dewanjee and Kahn have suggested that the affinity of ${ }^{99 \mathrm{~m}} \mathrm{Tc}-\mathrm{P}$ agents for binding with serum and other proteins plays a primary role in concentration of these agents in infarcted myocardium $(15,16)$. The present study was undertaken to clarify these important points regarding cellular localization and mechanisms of concentration of ${ }^{99 \mathrm{~m} T c-P}$ agents.

\section{METHODS}

General protocol. A total of 20 mongrel dogs were anesthetized with intravenous pentobarbital sodium $(30 \mathrm{mg} /$ $\mathrm{kg}$ ) and subjected to thoracotomy. The proximal left anterior

\footnotetext{
${ }^{1}$ Abbreviations used in this paper: ${ }^{131} \mathrm{I}-\mathrm{HSA}$, human serum albumin labeled with iodine-131; LAD, left anterior descending coronary artery; ${ }^{99 m} \mathrm{Tc}-\mathrm{P}$, technetium-99m-labeled, phosphorus-based radiopharmaceuticals; ${ }^{99 m}$ Tc-EHDP, ${ }^{99 m} \mathrm{Tc}$-stannous ethane-1-hydroxy-1,1, diphosphonate; ${ }^{99 \mathrm{~m}} \mathrm{TcO}_{4}$; free pertechnetate ion; ${ }^{99 \mathrm{~m}} \mathrm{Tc}$ cPYP, ${ }^{99 \mathrm{~m}} \mathrm{Tc}$-stannous pyrophosphate; ${ }^{3} \mathrm{H}-\mathrm{EHDP}$, tritiated EHDP.
}

descending coronary artery (LAD) was dissected free 1 to $2 \mathrm{~cm}$ from its origin and suture ligated. The chest was closed and the dog allowed to recover for 1 to 3 days. Thereafter, 15 dogs were injected with $7-10 \mathrm{mCi}$ of $99 \mathrm{~m}$ Tc-P prepared according to the manufacturer's instructions,

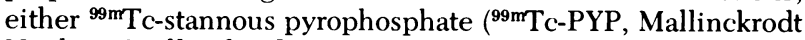
Nuclear, Mallinckrodt Inc., St. Louis, Mo.) or ${ }^{99 m}$ Tc-stannous ethane-1-hydroxy-1,1-diphosphonate $\left({ }^{99 \mathrm{~m}} \mathrm{Tc}\right.$-EHDP, Procter and Gamble Co., Cincinnati, Ohio.). The ${ }^{99 \mathrm{~m} T c-P}$ injection was followed 15 min later in some dogs by administration of $100-200 \mu \mathrm{Ci}$ of tritiated EHDP ( $\left.{ }^{3} \mathrm{H}-\mathrm{EHDP}\right)$ having a sp act of $20 \mu \mathrm{Ci} / \mathrm{mg}$. For autoradiography studies, the radiopharmaceuticals were administered directly into left atrial catheters in two dogs; in the other dogs, intravenous administration was used. Five additional dogs were given intravenous injections of $200-300 \mu \mathrm{Ci}$ of human serum albumin labeled with iodine-131 ( ${ }^{131}$ I-HSA) (Mallinckrodt Chemical Works, Mallinckrodt Inc.) at different intervals after LAD ligation. The dogs were lightly anesthetized with pentobarbital sodium and scintigrams were obtained in multiple projections at least $1 \mathrm{~h}$ after administration of radiopharmaceuticals with a Searle Pho-Gamma III HP scintillation camera (Searle Analytic Inc., Des Plaines, Ill.) with a high resolution collimator. After scintigraphy, the previously anesthetized dogs were sacrificed by administration of lethal doses of pentobarbital sodium or, for cell fractionation studies, by excision of the beating heart. Tissue samples were obtained at necropsy for one or more of the analyses described below.

Morphological and autoradiographic studies. For routine light microscopy, tissue blocks were fixed in phosphatebuffered $10 \%$ formalin and embedded in paraffin. Sections were stained with hematoxylin and eosin, by the periodic acid-Schiff method with and without prior diastase digestion and with the von Kossa method for calcium salts (3).

For correlative light and electron microscopic studies, samples were processed using the following methods: $(a)$ immersion fixation in $3 \%$ glutaraldehyde in $0.1 \mathrm{M}$ cacodylate buffer ( $\mathrm{pH} 7.4$ ) or $2 \%$ paraformaldehyde and $2.5 \%$ glutaraldehyde in $0.1 \mathrm{M}$ cacodylate buffer ( $\mathrm{pH} 7.4$ ), wash in cacodylatebuffered sucrose ( $\mathrm{pH} 7.4$ ), and post-fixation in $1 \%$ osmium tetroxide in veronal acetate buffer $(\mathrm{pH} \mathrm{7.4);(b)} \mathrm{fixation}$ directly in $1 \%$ osmium tetroxide in $0.1 \mathrm{M}$ phosphate buffer, or $(c)$ fixation directly in absolute alcohol. All samples were processed through alcohol and propylene oxide and embedded in Epon-(Shell Chemical Co., Houston, Tex.) Araldite (Ciba-Geigy Corp., Ardsley, N. Y.) mixture. 1- $\mu$ m thick sections for light microscopy were stained with toluidine blue. Thin sections were stained with uranyl acetate and lead citrate and examined in a JEOL $100 \mathrm{C}$ electron microscope (JEOL U.S.A. Inc., Medford, Mass.).

Autoradiographic detection of ${ }^{99 m} \mathrm{Tc}-\mathrm{P}$ or ${ }^{3} \mathrm{H}-\mathrm{EHDP}$ was attempted with various methods of tissue preparation, including fresh frozen sections, aldehyde or absolute alcohol fixation, and paraffin or epoxy embedment (20). Sections were dipped in Kodak NTB-2 emulsion (Eastman Kodak Co., Rochester, N. Y.), incubated for several weeks, and developed in Dektol (Eastman Kodak Co.) (20). Quantitation of the autoradiographs was obtained by performing grain counts with photographs obtained at standard magnification $(\times 400)$ from background regions without tissue as well as from all suitable microscopic fields from the tissue sections. Statistical analysis of the data was performed using the Student's $t$ test.

Assays for radioactivity and calcium. Hearts were divided into transverse slices and multiple transmural blocks, $0.5-1.0 \mathrm{~cm}$ wide, were obtained from areas of nor- 
mal and infarcted myocardium according to a previously described protocol (4). Sections for histology were obtained from the apical and basal surfaces of each block for correlation of histopathologic changes with assay results. Each block then was divided into multiple (usually four) samples extending from epicardium to endocardium. This procedure produced at least twelve small samples in the range of $200-300 \mathrm{mg}$ or less from each heart for analysis. Samples were also obtained from bone, skeletal muscle from thoracotomy sites, normal skeletal muscle, and breast.

All samples were placed in accurately weighed scintillation vials and gamma emission from ${ }^{99 \mathrm{~m} T c-P}$ or ${ }^{131}$ I-HSA quantitated with a gamma spectrometer (Packard model 5986, Packard Instrument Co., Inc., Downers Grove, Ill.). All data for ${ }^{99 \mathrm{~m}} \mathrm{Tc}-\mathrm{P}$ agents were tabulated as percentage of administered dose per gram of wet tissue weight from standards of the administered ${ }^{99 \mathrm{~m}} \mathrm{Tc}$. After decay of the ${ }^{99 \mathrm{~m}} \mathrm{Tc}$, the concentration of calcium was quantitated for each tissue after perchlorate wet oxidation preparation of the samples (21). The calcium was determined by atomic absorption with an adaptation of the Jarrell Ash Atomic Absorption Instrument (Jarrell Ash Div., Fisher Scientific Co., Waltham, Mass.), and results expressed as parts per million (ppm) (micrograms) per gram of wet tissue weight. For myocardial tissue samples from two dogs administered both ${ }^{99 m} \mathrm{Tc}-\mathrm{P}$ and ${ }^{3} \mathrm{H}$-EHDP, levels of ${ }^{99 \mathrm{~m}} \mathrm{Tc},{ }^{3} \mathrm{H}$, and calcium were quantitated in the same sample. After ${ }^{99 \mathrm{~m}} \mathrm{Tc}$ assay and decay, the tritiated EHDP levels were determined by combustion of the tissue in small quartz holders with a Packard model 305 oxidizer (Packard Instrument Co., Inc.). After combustion, the ash was quantitatively transferred in $3 \mathrm{~N}$ hydrochloric acid and calcium determined by atomic absorption spectroscopy as described above.

Statistical analysis of the data was performed by determination of Pearson correlation coefficients.

Cell fractionation studies. For these studies, the beating hearts were excised from two previously anesthetized dogs and placed immediately in ice-cold $0.25 \mathrm{M}$ sucrose. Cell fractionation was carried out by the procedure of Hogeboom (22) with $0.25 \mathrm{M}$ sucrose (pH 7.4) as the basic isolation medium, both with and without addition of $1 \mathrm{mM}$ EDTA. Samples, approximately 2-3 g each, were obtained from normal posterobasal myocardium and from peripheral regions of anterior infarcted myocardium. The chilled samples were homogenized in $10 \mathrm{ml}$ of medium in a Polytron PT 20 (Polytron Corp., Elkhart, Ind.) for four 30-s bursts. Each homogenate was centrifuged at $500 \mathrm{~g}$ for $15 \mathrm{~min}$ at $4^{\circ} \mathrm{C}$ in a Beckman J 21B centrifuge (Beckman Instruments, Inc., Spinco Div., Palo Alto, Calif.). The pellet (cell membranes and debris) was suspended in $10 \mathrm{ml}$ of medium. The supernate was centrifuged at $7,800 \mathrm{~g}$ for $15 \mathrm{~min}$ at $4^{\circ} \mathrm{C}$. The pellet (mitochondria) was washed twice in medium and finally suspended in $2 \mathrm{ml}$ of this solution. The supernate was centrifuged in a Beckman L2 ultracentrifuge (Beckman Instruments, Inc.) of rotor type at $80,000 \mathrm{~g}$ for $60 \mathrm{~min}$ at $4^{\circ} \mathrm{C}$. The pellet (microsomes) was washed twice with medium and finally suspended in $2 \mathrm{ml}$ of this solution. The soluble supernatant fraction after the 80,000-g centrifugation also was saved. Levels of ${ }^{99 \mathrm{~m}} \mathrm{Tc}$-P and calcium in each fraction were determined by methods described above. Protein content of each fraction was determined by the method of Lowry et al. (23). Aliquots of the particulate fractions were repelleted, fixed in aldehyde and osmium or directly in $1 \%$ phosphate-buffered osmium and, processed for electron microscopy.

In vitro studies of calcium binding. A series of in vitro experiments was performed to test the ability of various radiopharmaceuticals to complex with insoluble crystalline calcium hydroxyapatite and freshly precipitated amorphous calcium phosphate. The following agents were tested: (a) free pertechnetate ion $\left({ }^{99} \mathrm{TcO}_{4^{-}}\right) ;(b){ }^{99 \mathrm{~m}} \mathrm{Tc}-\mathrm{PYP}$ prepared from standard kits; and $(c){ }^{99 m}$ Tc-PYP activity of serum obtained from four normal dogs at various intervals after intravenous injection of ${ }^{99 \mathrm{~m}} \mathrm{Tc}-\mathrm{PYP}$. The amount of ${ }^{99 \mathrm{~m}} \mathrm{Tc}-\mathrm{P}$ bound to serum proteins was tested by precipitation of serum proteins with $0.1-0.2 \mathrm{ml}$ of serum mixed with $1.0 \mathrm{ml}$ of $10 \%$ TCA. The TCA-precipitated protein was centrifuged and the pellet washed and then radioassayed for ${ }^{99 \mathrm{~m}} \mathrm{~T} \mathrm{c}$.

For the hydroxyapatite binding studies, $50 \mathrm{mg}$ of synthetic hydroxyapatite (Stauffer Chemical Company, Westport, Conn.) was suspended in $1-5 \mathrm{ml}$ of normal saline and $0.1-0.2-\mathrm{ml}$ aliquots of ${ }^{99} \mathrm{~m} \mathrm{TCO}_{4^{-}},{ }^{99 \mathrm{~m}} \mathrm{Tc}-\mathrm{PYP}$, or serum added. After incubation at room temperature for $15 \mathrm{~min}$, the suspension was centrifuged, the precipitate was washed with normal saline, and the supernatant (including the saline wash) and precipitate fractions were counted for radioactivity.

For studies of binding to freshly precipitated amorphous calcium phosphate, $0.5 \mathrm{ml}$ of $0.1 \mathrm{M} \mathrm{CaCl}_{2}$ was added to $0.2-\mathrm{ml}$

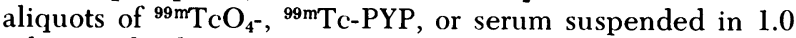
$\mathrm{ml}$ normal saline. Excess phosphate then was added to the solutions in the form of $1.5 \mathrm{ml}$ of $0.2 \mathrm{M}$ sodium phosphate (pH 6.5) so as to form a precipitate of amorphous calcium phosphate $(24,25)$. The suspension was centrifuged, the precipitate was washed in saline, and the supernatant (including saline wash) and precipitate fractions were counted for radioactivity.

\section{RESULTS}

Scintigraphic findings. The ${ }^{99 \mathrm{~m}} \mathrm{Tc}-\mathrm{P}$ scintigrams showed intense radioactivity in the following regions: (a) bony skeleton in all dogs; (b) anterior myocardium corresponding to sites of anterior myocardial infarcts in all dogs; $(c)$ sites of left lateral thoracotomies in all dogs; and $(d)$ mammary glands in one dog. Positive ${ }^{99 m}$ Tc-P myocardial scintigrams in most dogs showed a prominent doughnut pattern in the anterior and left anterior oblique projections characterized by a zone of intense radioactivity surrounding a central region of variable size with decreased radioactivity $(3,4)$.

Morphological and autoradiographic findings. Mammary glands identified scintigraphically were enlarged and showed typical histologic features of lactation. The lumens of the ducts were filled with basophilic material rich in calcium salts (von Kossa stain) (Figs. 1A and B). Sections of thoracotomy sites showed extensive necrosis of skeletal muscle and prominent infiltration by neutrophils. The necrotic skeletal muscle cells showed prominent cytoplasmic disruption, contraction band formation and multifocal calcification (von Kossa stain) (Figs. 1C and D). Hearts with proximal LAD occlusion had transmural anterior infarcts with histopathologically distinct central and peripheral regions as previously described $(3,4)$.

Autoradiographic localization of ${ }^{99 \mathrm{~m}} \mathrm{Tc}-\mathrm{P}$ or ${ }^{3} \mathrm{H}-$ EHDP in the myocardial infarcts was not successful using standard methods of tissue preparation (20), 

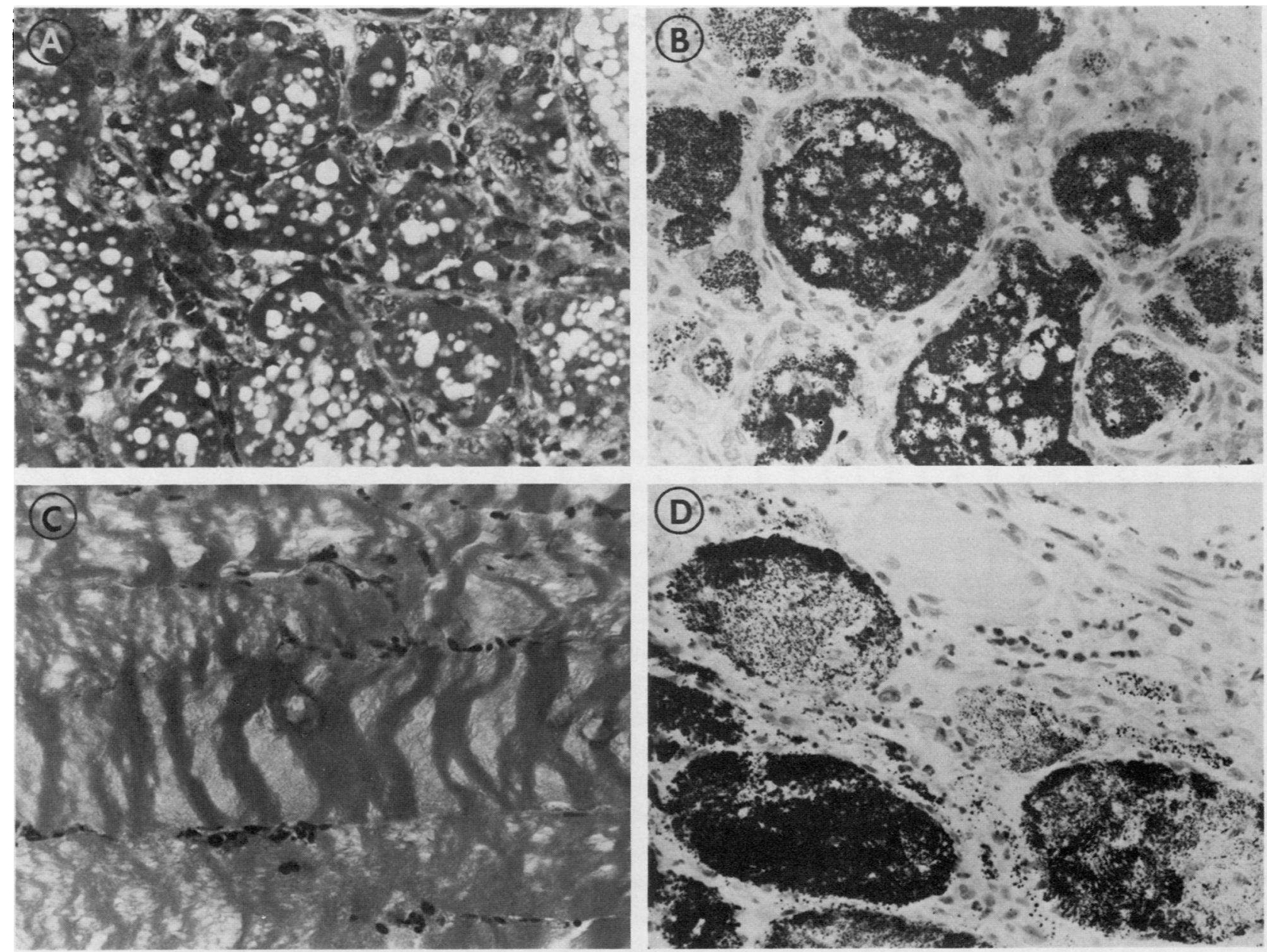

FIGURE 1 Histology of sites of ${ }^{99 m}$ Tc-P uptake other than myocardium. (A) Acinar ducts of lactating breast are filled with basophilic secretion which contains fat globules. (B) The ductular secretion of lactating breast is rich in calcium salts. (C) Necrotic thoracotomy muscle exhibits myofibrillar disruption and neutrophilic infiltrate. (D) Many necrotic skeletal muscle fibers contain granular calcific deposits. $A$ and $C$, hematoxylin and eosin stains; $B$ and D, von Kossa stains for calcium salts; all $\times 300$.

but was obtained with the following protocol: injection of $200 \mu \mathrm{Ci}$ of ${ }^{3} \mathrm{H}$-EHDP directly into the left atrium, fixation of tissues in absolute alcohol, and exposure of epoxy-embedded sections to emulsion for $6 \mathrm{wk}$ (Table I, Fig. 2). It was found that significant loss of tissue radioactivity and calcium occurred with aldehyde and osmium fixatives, whereas minimal loss (less than 5\%) occurred with alcohol fixatives (Carnoy's solution and absolute alcohol). Furthermore, use of ${ }^{3} \mathrm{H}$ EHDP overcame difficulties encountered with ${ }^{99 \mathrm{~m}} \mathrm{Tc}$, a short half-life gamma emitter with some secondary beta and Auger production. Analysis of tissue samples from two dogs demonstrated a close correlation ( $r=0.95$ and 0.99$)$ between ${ }^{99 m} \mathrm{Tc}-\mathrm{P}$ and ${ }^{3} \mathrm{H}-\mathrm{EHDP}$ levels, indicating that ${ }^{3} \mathrm{H}-\mathrm{EHDP}$ autoradiography accurately reflected the localization of the complete ${ }^{99 \mathrm{~m}} \mathrm{Tc}-\mathrm{P}$ radiopharmaceuticals (Table II).
Autoradiographic findings in absolute alcohol fixed, epoxy embedded sections from two dogs with 44 to 48-h-old myocardial infarcts revealed selective localization of increased ${ }^{3} \mathrm{H}$-EHDP activity in the peripheral regions of acute myocardial infarcts (Table I, Fig. 2). Prominent and extensive labeling occurred over necrotic muscle cells of the infarct periphery, which exhibited widespread hypercontraction of myofibrils, focal deposition of fibrin-like material, and selective accumulation of relatively insoluble calcium deposits primarily but not exclusively in mitochondria (26-31) (Figs. 3 and 4). Some labeling of interstitial cells was present, but little activity was noted over neutrophils. Interstitial regions adjacent to some arterioles also exhibited prominent labeling.

Some of the sections for autoradiography contained a mixture of necrotic myocardium and border zone myo- 
TABLE I

Autoradiographic Localization of Tritiated Diphosphonate in Two Canine Hearts with LAD Occlusion for 2 Days

\begin{tabular}{lc}
\hline \multicolumn{1}{c}{ Area } & $\begin{array}{c}\text { Labeling } \\
\text { index* }\end{array}$ \\
\hline Normal myocardium & $\begin{array}{c}6.3 \pm 2.1 \\
(n=10) \downarrow\end{array}$ \\
Border myocardium without histologic & $12.3 \pm 2.6 \S$ \\
$\quad$ damage & $(n=11)$ \\
Border myocardium with severely damaged & $143.4 \pm 20.6^{\| \prime}$ \\
muscle cells immediately adjacent to & $(n=10)$ \\
necrotic muscle cells & \\
Peripheral zone of infarct with necrotic & $167.1 \pm 35.9^{\prime \prime}$ \\
muscle cells & $(n=18)$ \\
Central zone of infarct with necrotic muscle & $1.0 \pm 0.6 \S$ \\
cells & $(n=8)$ \\
\hline
\end{tabular}

Data are given as mean $\pm \mathrm{SEM}$.

* Labeling index is the number of developed silver grains over tissue minus developed grains over background per unit area $\left(0.0054 \mu \mathrm{m}^{2}\right)$.

$\$$ Number of microscopic fields examined.

$\S P<0.05$ when compared with normal myocardial values (Student's $t$ test).

" $P<0.0005$ when compared with normal myocardial values (Student's $t$ test).

cardium in which muscle cells did not show histologic evidence of necrosis but exhibited prominent accumulation of lipid droplets indicative of significant damage and metabolic impairment (32). Electron microscopic examination confirmed the occurrence of abnormal accumulation of lipid droplets in these border zone muscle cells (Fig. 5). Some of these muscle cells were otherwise ultrastructurally intact, but others showed additional alterations, including focal lysis of myofibrils, vacuolar dilatation of sarcoplasmic reticulum and $\mathrm{T}$ tubules, mitochondria with a condensed configuration, and swollen mitochondria with early calcium deposition in the form of small, annular, granular, amorphous, or microcrystalline calcium phosphate deposits (26-30) (Fig. 5). In the autoradiographs the damaged border zone muscle cells as well as necrotic muscle cells showed significant labeling (Table I, Fig. 2). In other sections obtained within $1 \mathrm{~cm}$ of the gross edges of the infarcts, border zone muscle cells showed generally low levels of radio- activity, but intense labeling of a few necrotic muscle cells was observed in these regions (Fig. 2).

Tissue levels of ${ }^{99 m} T c-P$ agents and calcium. Analysis of tissue levels of ${ }^{99 \mathrm{~m}} \mathrm{Tc}-\mathrm{P}$ and calcium was performed in eight dogs sacrificed $1-2 \mathrm{~h}$ after administration of the radionuclides (Figs. 6 and 7, Table II). Values for ${ }^{99 \mathrm{~m} T c-P}\left(\%\right.$ dose/g wet weight $\left.\times 10^{3}\right)$ and calcium $(\mathrm{ppm} / \mathrm{g}$ wet weight), respectively, were 3.3 \pm 1.3 (standard error of mean) and $17.4 \pm 1.7$ in normal myocardium and $0.60 \pm 0.08$ and $14.8 \pm 4.8$ in normal skeletal muscle of the eight dogs. Elevated levels of calcium were measured in all sites visualized scint1graphically, namely, bone, lactating breast, necrotic thoracotomy muscle, and infarcted myocardium; however, levels of ${ }^{99 \mathrm{~m}} \mathrm{Tc}-\mathrm{P}$ uptake in the various tissues did not correlate in a linear manner with calcium concentration (Fig. 6). A more detailed analysis was undertaken of the distribution of ${ }^{99 \mathrm{~m}} \mathrm{Tc}-\mathrm{P}$ and calcium in infarcted myocardium. Study of corresponding histologic sections allowed assignment of samples for tissue assay to the various histopathologically defined infarct zones $(3,4)$. Total number of infarct samples assayed for each dog ranged from 15 to 35 . To overcome dog to dog variability in absolute ${ }^{99 \mathrm{~m}} \mathrm{Tc}-\mathrm{P}$ and calcium levels, abnormal-to-normal ratios were calculated for each dog (Fig. 7). The data demonstrated that maximal concentration of ${ }^{99 \mathrm{~m}} \mathrm{Tc}-\mathrm{P}$ (average mean 17 times normal) and calcium (16.7 times normal) occurred in the peripheral zones of infarcts with extensive to homogeneous necrosis and variable degrees of muscle cell calcification. Border zones of the infarcts with focal necrosis also had high ${ }^{99 \mathrm{~m}} \mathrm{Tc}$-P levels (11 times normal) and modestly elevated calcium levels (3 times normal). Central zones of the infarcts had moderately elevated levels of ${ }^{99 \mathrm{~m}} \mathrm{Tc}-\mathrm{P}$ (6.5 times normal) and calcium (6.2 times normal). Analysis of the absolute (Fig. 6) or normalized (Fig. 7) values showed that the levels of ${ }^{99 m} \mathrm{Tc}-\mathrm{P}$ uptake did not correlate in a linear manner with the levels of calcium in the infarcts. In addition to inter-dog comparisons, a statistical analysis was made of the relationship between absolute values of ${ }^{99 \mathrm{~m}} \mathrm{Tc}-\mathrm{P}$ and calcium in the multiple samples from each infarct, and the results revealed a significant relationship between ${ }^{99 \mathrm{~m}} \mathrm{Tc}$ activity and calcium levels in five of the eight dogs (Table II).

Cell fractionation studies. The distribution of ${ }^{99 \mathrm{~m}} \mathrm{Tc}-\mathrm{P}$ and calcium in the four fractions from normal and infarcted myocardium of two dogs with 24-h-old infarcts is presented in Table III. Major localization

FIGURE 2 Autoradiographic localization of ${ }^{3} \mathrm{H}$-EHDP in 2-day-old myocardial infarcts. (A) Routine preparations shows myofibrillar disruption and contraction band formation in necrotic muscle cells of the infarct periphery, $\times 500$. (B) Autoradiography demonstrates extensive labeling of necrotic peripheral zone muscle cells, $\times 500$. (C) Routine preparation shows mixture of necrotic muscle cells (bottom) and injured border zone muscle cells which contain numerous lipid droplets (top), $\times 980$. (D) Autoradiograph demonstrates significant 

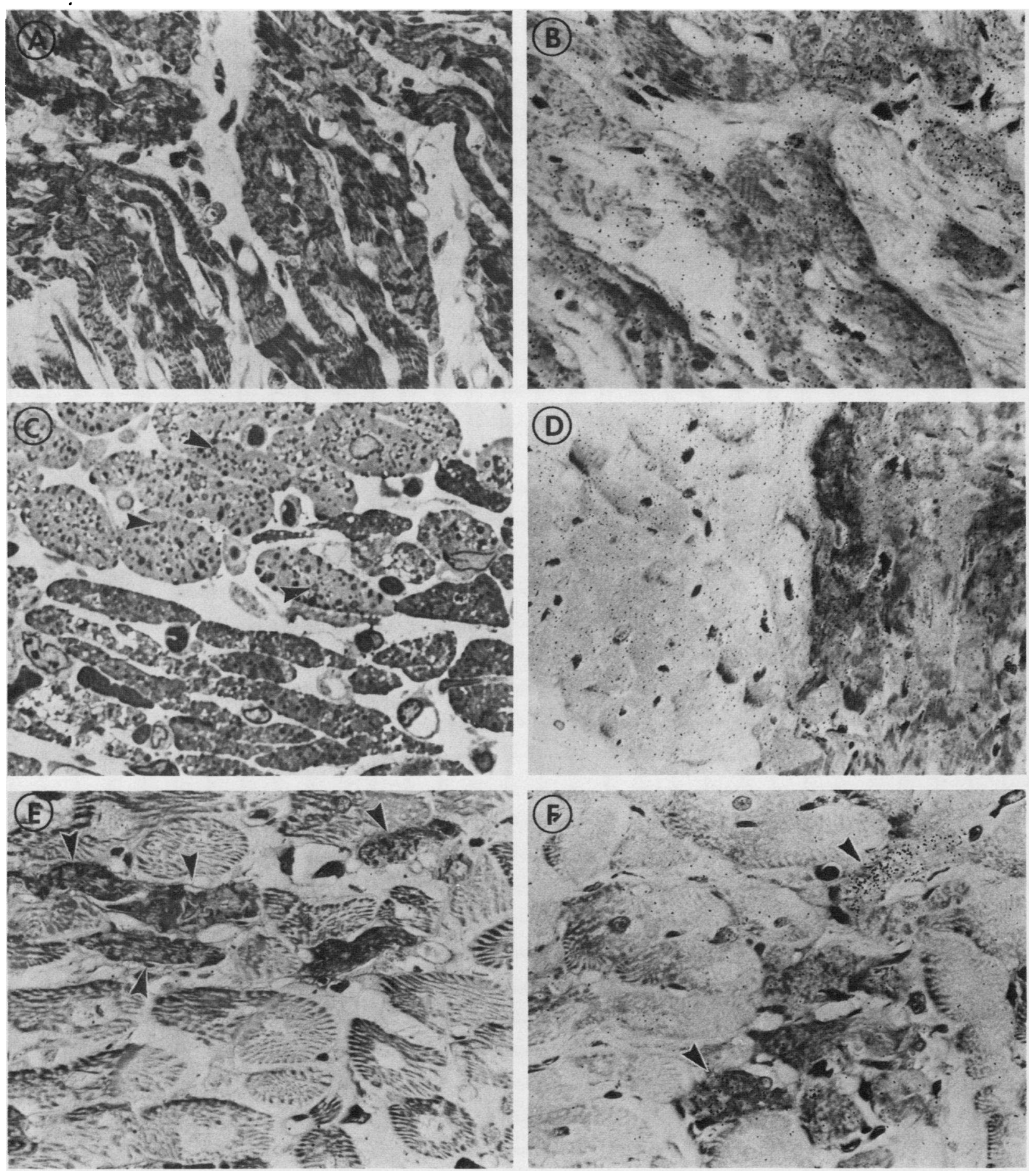

labeling of necrotic muscle cells (right) and adjacent damaged border zone muscle cells (left), $\times 290$. (E) Routine preparation shows rare necrotic muscle cells (arrows) in grossly normal border myocardium obtained within $1 \mathrm{~cm}$ of the gross edge of the infarct, $\times 500$. (F) Autoradiograph from the same block shown in E demonstrates intense labeling of necrotic muscle cells (arrows) and low levels of radioactivity over adjacent border zone muscle cells, $\times 500$. Epoxy sections stained with toluidine blue; A-B, D-F, absolute alcohol fixation, $\mathrm{C}$, aldehyde-osmium fixation. 
TABLE II

Correlation of Absolute Levels of Technetium-99m Phosphorus Agents, Tritiated Diphosphonate, and Calcium in Canine Myocardial Infarcts

\begin{tabular}{|c|c|c|c|c|c|c|c|}
\hline Dog no. & Age of infarct & ${ }^{99 \mathrm{~m}} \mathrm{TC}-\mathrm{P}$ & ${ }^{3} \mathrm{H}-\mathrm{EHDP}$ & Calcium & No. samples & $P$ & $r$ \\
\hline & h & ") dose/g $\times 10^{3}$ & $\%$ dose/g $\times 10^{3}$ & $\mathrm{~m} \mathrm{~mm} / \mathrm{g}$ & & & \\
\hline \multirow[t]{2}{*}{$1^{*}$} & 24 & $25.2 \pm 2.7$ & $32.2 \pm 3.3$ & & 42 & 0.0001 & 0.95 \\
\hline & & $26.4 \pm 3.1$ & & $369.0 \pm 44.5$ & 35 & 0.0001 & 0.92 \\
\hline \multirow[t]{2}{*}{$2+$} & 20 & $16.8 \pm 3.2$ & $16.7 \pm 3.2$ & & 27 & 0.0001 & 0.99 \\
\hline & & $20.3 \pm 4.1$ & & $76.8 \pm 11.6$ & 19 & 0.0001 & 0.88 \\
\hline $3^{*}$ & 48 & $103.1 \pm 14.7$ & & $162.2 \pm 16.1$ & 24 & 0.77 & -0.06 \\
\hline $4 \hbar$ & 42 & $118.2 \pm 16.2$ & & $194.9 \pm 20.6$ & 24 & 0.89 & -0.03 \\
\hline $5^{*}$ & 36 & $31.1 \pm 3.8$ & & $512.1 \pm 75.9$ & 20 & 0.0002 & 0.78 \\
\hline $6^{*}$ & 72 & $9.4 \pm 0.7$ & & $86.8 \pm 5.9$ & 20 & 0.006 & 0.60 \\
\hline $7 \ddagger$ & 24 & $19.5 \pm 3.5$ & & $87.1 \pm 5.4$ & 15 & 0.53 & -0.20 \\
\hline $8+$ & 20 & $8.7 \pm 1.7$ & & $118.8 \pm 16.7$ & 16 & 0.0015 & 0.73 \\
\hline
\end{tabular}

Data are given as mean $\pm \mathrm{SEM}$.

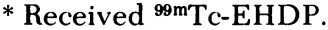

$\$$ Received ${ }^{99 \mathrm{~m}} \mathrm{Tc}$-PYP.

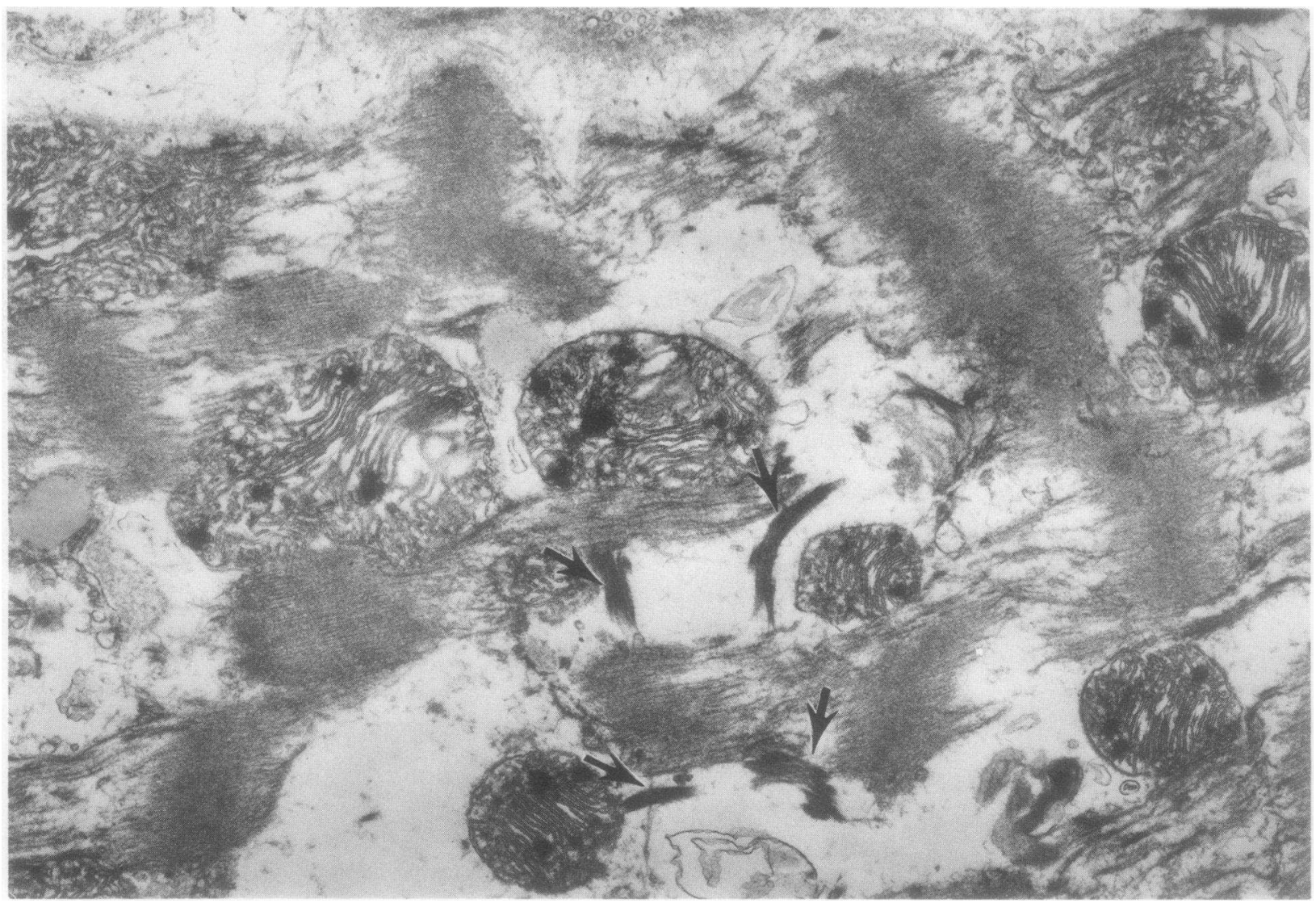

FIGURE 3 Electron micrograph of necrotic peripheral zone muscle cell. The cell exhibits lysis of the plasma membrane, myofibrillar disruption and contraction bands, glycogen depletion, lipid droplets, and strands of electron dense material with features of partially polymerized fibrin (arrows). The mitochondria are devoid of calcific deposits, but contain amorphous matrix (flocculent) densities which are composed primarily of osmiophilic organic material and which are characteristic of advanced irreversible injury. Direct phosphate-buffered osmium fixation, $\times 15,100$. 

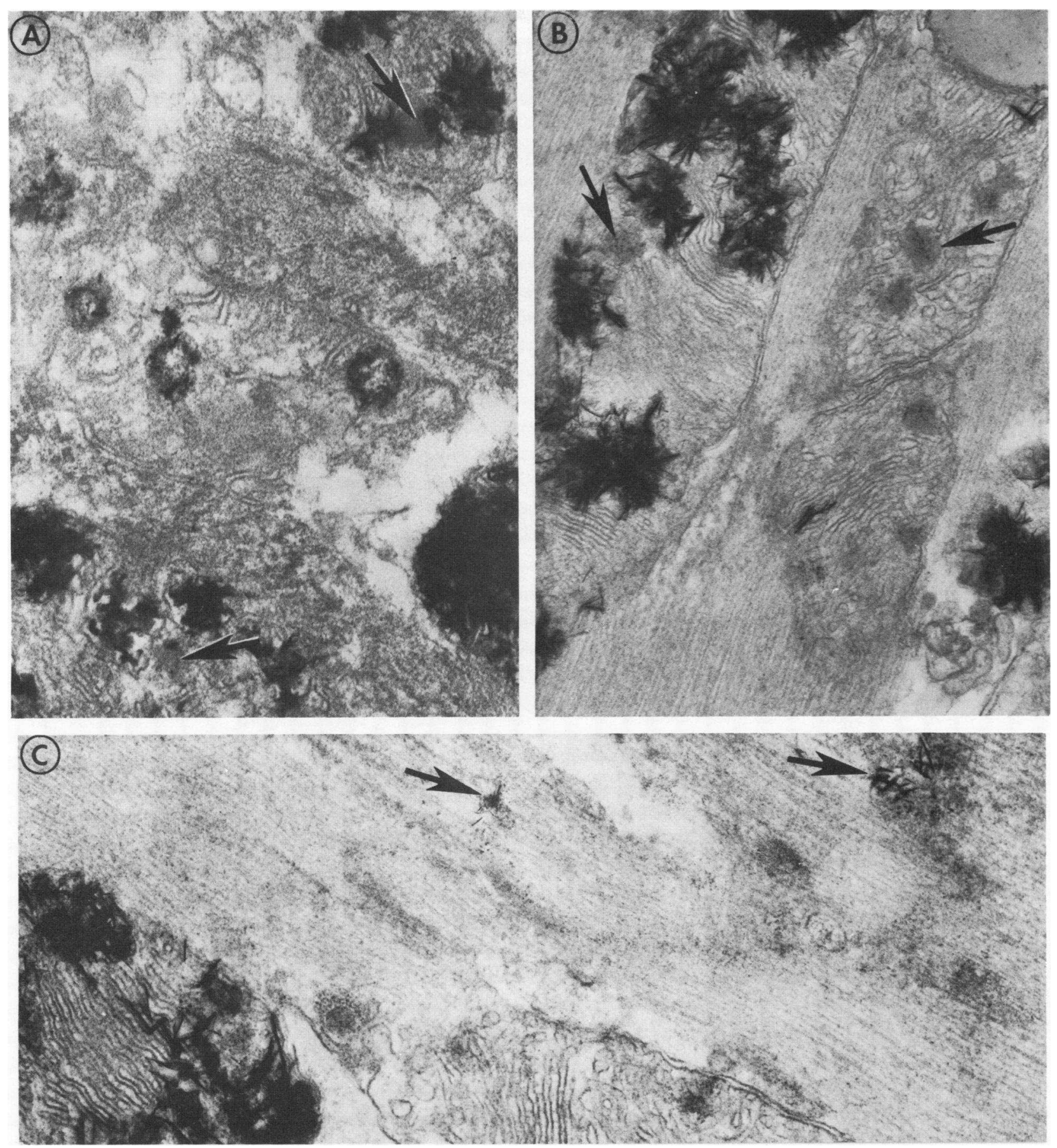

FIGURE 4 Electron micrographs of necrotic peripheral zone muscle cells with calcific deposits. (A) The mitochondria exhibit very electron dense, calcific deposits as well as less dense, amorphous matrix (flocculent) densities (arrows). The calcific deposits in some areas show the spicular appearance of hydroxyapatite-like crystals. (B) These mitochondrial calcific deposits have a more prominent spicular appearance. Amorphous matrix densities also are present (arrows). (C) In addition to the spicular calcific deposits in a mitochondrion, a few small spicular deposits are also localized to the myofibrils (arrows). (A) Direct phosphatebuffered osmium fixation, $\times 52,400$. (B) Double fixation in aldehyde and osmium, $\times 65,000$. (C) Double fixation in aldehyde and osmium, $\times 50,400$. 


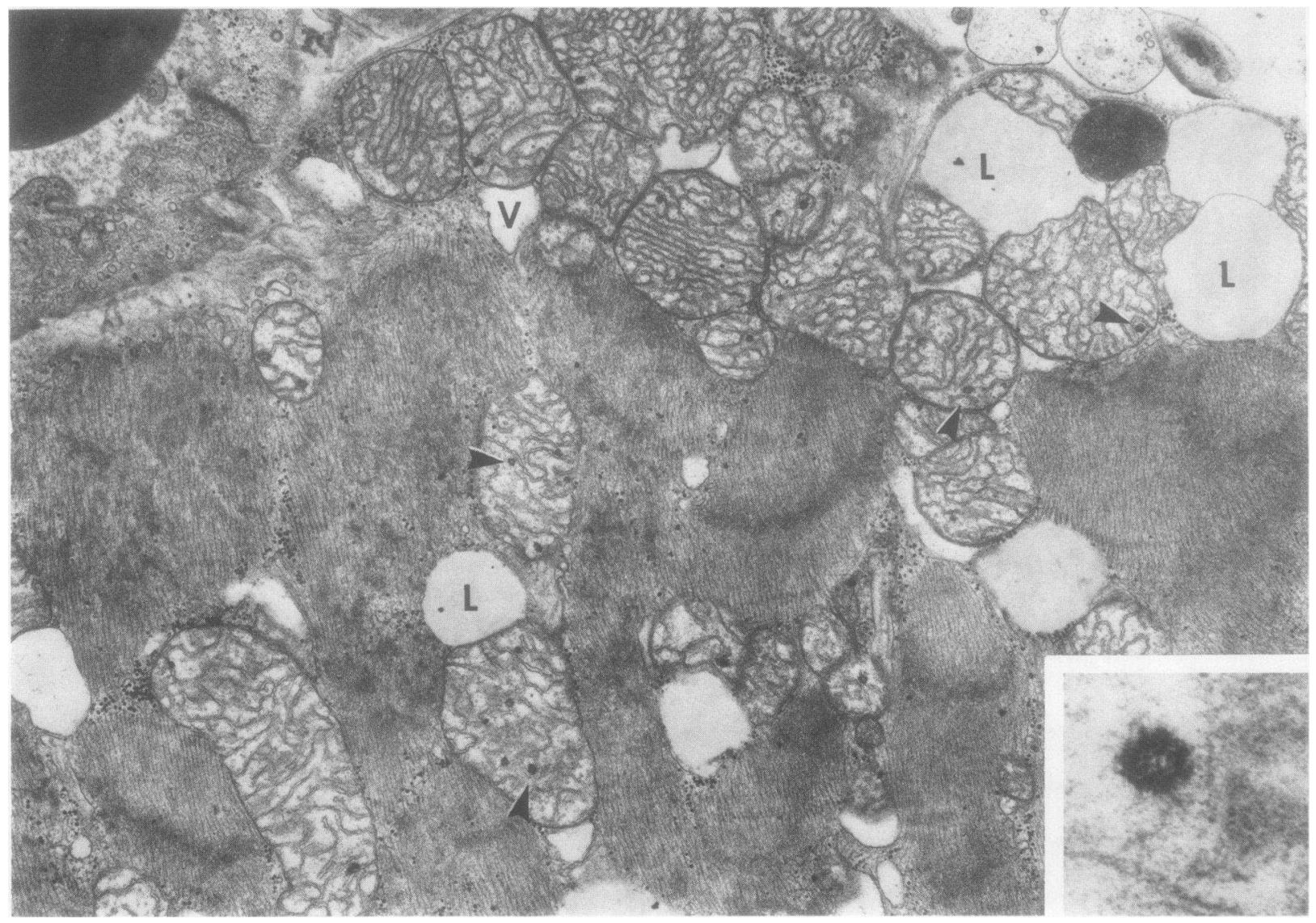

FIGURE 5 Electron micrograph of damaged border zone muscle cell. The muscle cell exhibits intact myofibrils, some glycogen granules, vacuolated sarcoplasmic reticulum (V), numerous lipid droplets (L), and swollen mitochondria which are devoid of amorphous matrix densities but contain small, electron dense deposits of early calcification (arrows). Phosphate-buffered osmium fixation, $\times 16,100$. (Inset) High magnification view of electron dense, annular, granular deposit characteristic of amorphous (or microcrystalline) calcium phosphate. $\times 99,000$.

of ${ }^{99 \mathrm{~m}} \mathrm{Tc}-\mathrm{P}$ and calcium occurred in the membranedebris and soluble supernatant fractions, with the soluble supernate showing higher ${ }^{99 \mathrm{~m}} \mathrm{Tc}-\mathrm{P}$ and calcium levels when samples were fractionated in the presence of $1 \mathrm{mM}$ EDTA. The distribution of recovered protein remained relatively constant in fractions obtained with or without $1 \mathrm{mM}$ EDTA. The mitochondrial and microsomal fractions each contained low percentages of total recovered ${ }^{99 \mathrm{~m}} \mathrm{Tc}-\mathrm{P}$ and calcium, whether fractionation was performed with or without $1 \mathrm{mM}$ EDTA. On electron microscopic examination, fractions from normal myocardium showed well preserved mitochondria; however, fractions from infarcted myocardium contained only fragments of disrupted mitochondria and swollen mitochondria with multiple amorphous matrix densities (Fig. 8). Mitochondrial fractions from infarcted myocardium, isolated either with or without EDTA, did not exhibit mitochondria with calcific deposits as were observed in tissue sections of infarcted myocardium.

Comparison of ${ }^{99 m} \mathrm{Tc}-\mathrm{P}$ and protein uptake in anterior myocardial infarcts. Table IV summarizes comparative evaluations of the uptake rate and level of concentration of ${ }^{99 \mathrm{~m}} \mathrm{Tc}-\mathrm{P}$ and ${ }^{131} \mathrm{I}$-HSA in seven dogs with anterior myocardial infarcts. Concentration of ${ }^{131}$ I-HSA in infarcted myocardium was modest and only reached a level of 3.8 times normal myocardium after a prolonged circulation time of $96 \mathrm{~h}$ which allowed for significant blood pool clearance; concentration in bone also was minimal. In contrast, ${ }^{99 m}$ Tc-PYP was highly concentrated in infarcted myocardium and bone after circulation for $6 \mathrm{~h}$.

In vitro studies of calcium binding. Table V summarizes a comparative analysis of the ability of ${ }^{99} \mathrm{TcO}_{4^{-}}$, freshly prepared ${ }^{99 \mathrm{~m}} \mathrm{Tc}-\mathrm{PYP}$, and serum ${ }^{99}$ Tc-PYP to complex with insoluble crystalline cal- 

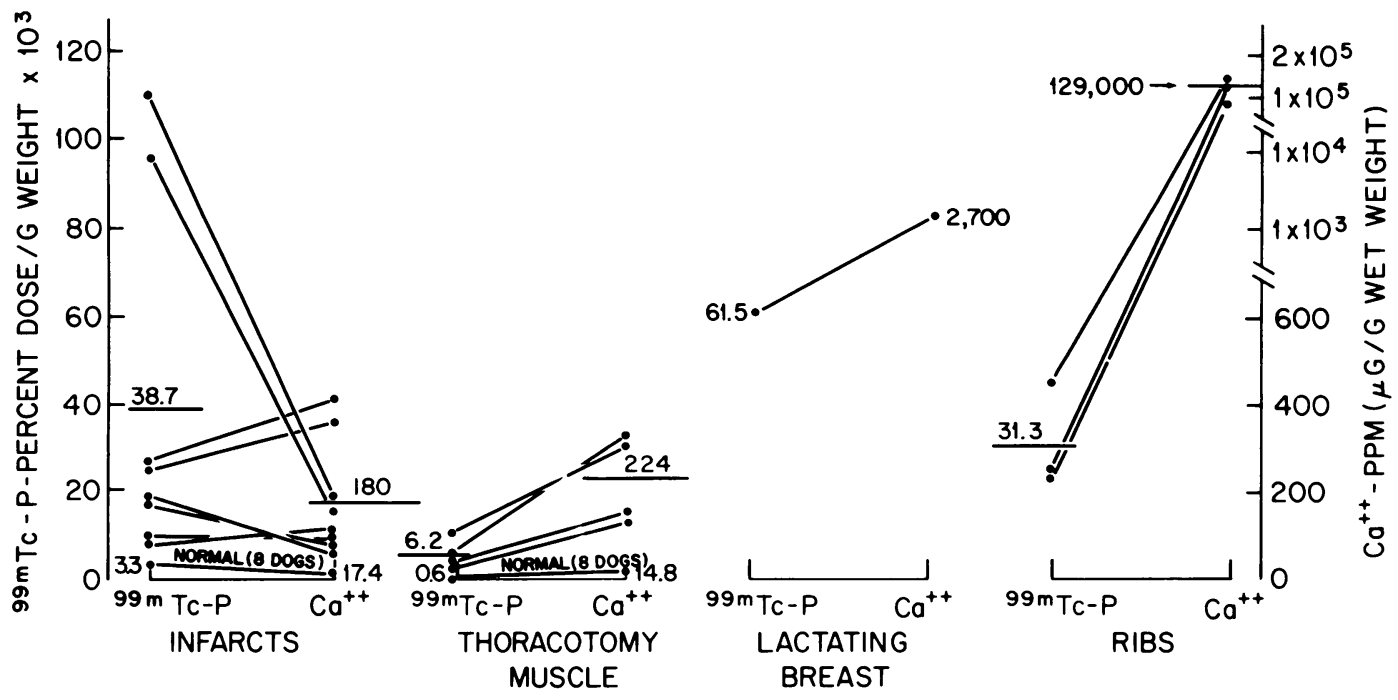

FIgURE 6 Absolute levels of calcium and ${ }^{99 m}$ Tc-P radiopharmaceuticals in sites of scintigraphically detected activity in eight dogs with proximal LAD ligation for 1-3 days. The numerical values shown represent average mean values of ${ }^{99 \mathrm{~m}} \mathrm{Tc}-\mathrm{P}$ and calcium for infarcted myocardium, normal myocardium, necrotic thoracotomy muscle, normal skeletal muscle, lactating breast $(n=1)$, and rib.

cium hydroxyapatite and freshly precipitated amorphous calcium phosphate $(24,25)$. As expected, ${ }^{99 m}$ Tc-PYP showed essentially complete binding to hydroxyapatite and amorphous calcium phosphate, whereas ${ }^{99} \mathrm{TCO}_{4}$ - demonstrated essentially no binding. Analysis of sera obtained from four dogs at various intervals after ${ }^{99 m} \mathrm{Tc}-\mathrm{PYP}$ injection revealed that $51 \%$ of total ${ }^{99 m}$ Tc-PYP activity in serum $5 \mathrm{~min}$ after injection was complexed with serum proteins and that the proportion of protein-bound ${ }^{99 \mathrm{~m} T \mathrm{Tc}-\mathrm{PYP}}$ tended to increase, especially at intervals of over $1-\mathrm{h}$ circulation time. In spite of significant serum protein binding, ${ }^{99 \mathrm{~m}} \mathrm{Tc}-\mathrm{PYP}$ in serum retained a marked affinity for sorption with hydroxyapatite and amorphous calcium phosphate. Serum ${ }^{99 \mathrm{~m}}$ Tc-PYP activity obtained at 5 min exhibited $84.6 \%$ complexing with hydroxyapatite and $82.4 \%$ complexing with amorphous calcium phosphate. Sorption affinity for the two calcium phosphate species showed a progressive decrease with circulation time, but over $50 \%$ sorption was observed with serum obtained as long as $1 \mathrm{~h}$ after ${ }^{99 \mathrm{~m} T c-P Y P}$ injection.

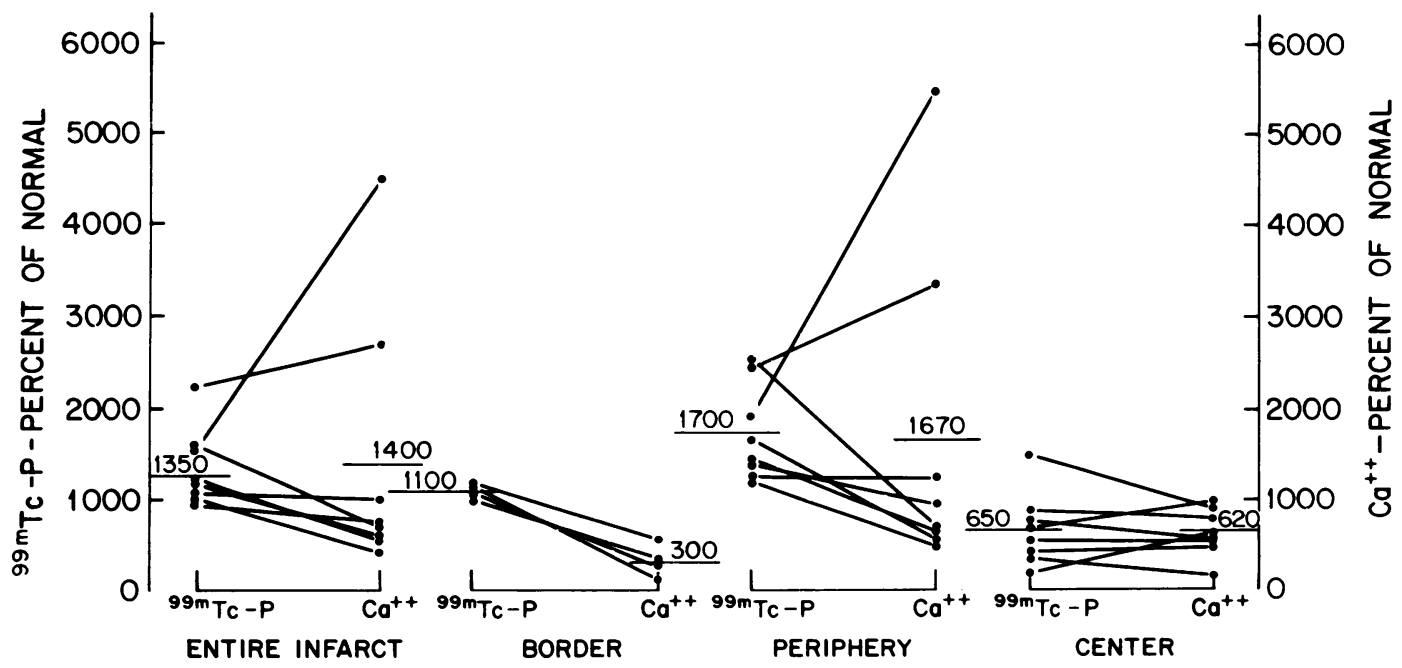

FIgURE 7 Abnormal-to-normal ratios of calcium and ${ }^{99 \mathrm{~m}} \mathrm{Tc}-\mathrm{P}$ radiopharmaceuticals in different zones of acute myocardial infarcts in eight dogs. 
TABLE III

Cell Fractionation Data from Two Canine Hearts with 24-h-Old Infarcts

\begin{tabular}{|c|c|c|c|c|c|c|c|}
\hline \multirow[b]{2}{*}{ Fractions } & \multicolumn{3}{|c|}{ Medium: $0.25 \mathrm{M}$ sucrose without EDTA } & \multicolumn{4}{|c|}{ Medium: $0.25 \mathrm{M}$ sucrose plus $1 \mathrm{mM}$ EDTA } \\
\hline & $\operatorname{sem} \mathrm{TC}-\mathrm{F}$ & Calcium & Protein & \multicolumn{2}{|c|}{${ }^{\oplus \oplus m \mathrm{Tc}-\mathrm{P}}$} & Calcium & Protein \\
\hline & $\%$ dose $\lg \times 10^{3}$ & $\mathrm{pm} / \mathrm{g}$ & $\mathrm{mg} / \mathrm{g}$ & $\%$ dose & $\lg \times 10^{3}$ & $\mathrm{ppm} / \mathrm{g}$ & $\mathrm{mg} / \mathrm{g}$ \\
\hline \multicolumn{8}{|l|}{ Debris } \\
\hline Normal & $0.32(31.7 \%)$ & $40.9(82.6 \%)$ & $98.1(78.2 \%)$ & 0.28 & $(28.0 \%)$ & $8.2(19.1 \%)$ & $109.1(81.5 \%)$ \\
\hline Infarct & $13.9 \quad(64.4 \%)$ & $132.5(79.3 \%)$ & $77.6(72.0 \%)$ & 9.5 & $(46.1 \%)$ & $34.1(23.1 \%)$ & $96.2(80.6 \%)$ \\
\hline \multicolumn{8}{|c|}{ Mitochondria } \\
\hline Normal & $0.01 \quad(1.0 \%)$ & $2.5 \quad(5.0 \%)$ & $1.7 \quad(1.4 \%)$ & 0.007 & $(0.7 \%)$ & $4.7(11.0 \%)$ & $(1.0 \%)$ \\
\hline Infarct & $0.19(0.9 \%)$ & $2.9 \quad(1.7 \%)$ & $(1.5 \%)$ & 0.14 & $(0.7 \%)$ & $2.2(1.5 \%)$ & $1.4(1.2 \%)$ \\
\hline \multicolumn{8}{|l|}{ Microsomes } \\
\hline Normal & $(1.0 \%)$ & $0.8 \quad(1.6 \%)$ & $(0.9 \%)$ & 0.006 & $(0.6 \%)$ & $2.2(5.1 \%)$ & $(0.8 \%)$ \\
\hline Infarct & $0.13 \quad(0.6 \%)$ & $2.7 \quad(1.6 \%)$ & $1.6(1.5 \%)$ & 0.11 & $(0.5 \%)$ & $3.6 \quad(2.4 \%)$ & $1.3(1.1 \%)$ \\
\hline \multicolumn{8}{|l|}{ Supernatant } \\
\hline Normal & $0.67(66.3 \%)$ & $5.3(10.7 \%)$ & $24.5(19.5 \%)$ & 0.71 & $(71.0 \%)$ & $27.8(64.8 \%)$ & $22.3(16.7 \%)$ \\
\hline Infarct & $7.4 \quad(34.3 \%)$ & $28.9(17.3 \%)$ & $27.0(25.0 \%)$ & 10.8 & $(52.4 \%)$ & $107.5(72.9 \%)$ & $20.4(17.1 \%)$ \\
\hline
\end{tabular}

\section{DISCUSSION}

The data obtained in the present study indicate that: (a) ${ }^{99 \mathrm{~m}} \mathrm{Tc}-\mathrm{P}$ uptake in acutely infarcted myocardium, and possibly other types of soft tissue damage, is limited to necrotic and severely injured cells; $(b)$ tissue uptake of ${ }^{99 \mathrm{~m} T c-P}$ agents is localized selectively to sites with elevated calcium levels although a consistent linear relationship does not occur between total tissue calcium concentration and levels of ${ }^{99 \mathrm{~m} T c-P}$ uptake; and $(c)$ concentration of ${ }^{99 \mathrm{~m}} \mathrm{Tc}-\mathrm{P}$ appears to result from selective sorption of ${ }^{99 \mathrm{~m}} \mathrm{Tc}-\mathrm{P}$ with various forms of tissue calcium stores, including amorphous calcium phosphate, crystalline hydroxyapatite and calcium complexed with myofibrils, and other macromolecules, possibly supplemented by calcium-independent complexing with organic macromolecules (Fig. 9).

Our autoradiographic findings have provided insight into questions regarding the severity of cellular injury required for ${ }^{99 \mathrm{~m}} \mathrm{Tc}-\mathrm{P}$ concentration. Although autoradiography was performed with ${ }^{3} \mathrm{H}$-EHDP not complexed with ${ }^{99 \mathrm{~m} T \mathrm{~T}}$, a strong correlation $(r>0.95)$ was found between tissue levels of ${ }^{99 \mathrm{~m}} \mathrm{Tc}-\mathrm{P}$ and ${ }^{3} \mathrm{H}-$ EHDP. The autoradiographic findings, therefore, indicate that some uptake of ${ }^{99 \mathrm{~m}} \mathrm{Tc}-\mathrm{P}$ radiopharmaceuticals occurs in significantly damaged border zone muscle cells (32) in addition to more widespread labeling of frankly necrotic muscle cells throughout the infarct periphery. In addition, intense labeling occurred over individual necrotic cells in border zone regions with generally low levels of radioactivity. These findings demonstrate that the observed lack of correlation between extent of histologically demonstrable necrosis and level of ${ }^{99 \mathrm{~m}} \mathrm{Tc}-\mathrm{P}$ uptake in a given infarct sample is due to labeling of severely damaged border zone muscle cells in addition to greater blood flow and delivery of ${ }^{99 \mathrm{~m}} \mathrm{Tc}-\mathrm{P}$ to partially necrotic regions at the edges of the infarcts (3-12). Our electron microscopic studies showed that the border zone muscle cells with increased radiopharmaceutical uptake exhibit significant damage in the form of abnormal lipid accumulation, focal myofibrillar lysis and mitochondrial alterations, including early calcium deposition. Further studies are needed to determine the ultimate fate of damaged border zone muscle cells with increased ${ }^{99 m}$ Tc-P uptake. Nevertheless, the demonstration of early mitochondrial calcification in border zone muscle cells supports the view that injury in at least some of these cells had progressed to an early stage of irreversible damage (26-28, 33-35). It seems unlikely that cellular injury of the type manifested by autoradiographically labeled border zone myocardium occurs in the absence of associated cellular necrosis.

Considerable controversy has arisen regarding mechanisms of tissue concentration of ${ }^{99 \mathrm{~m} T c-P}$ agents. Although the theoretical basis for the development of ${ }^{99 \mathrm{~m}} \mathrm{Tc}-\mathrm{P}$ scintigraphy of bone and acute myocardial infarcts was adsorption of these agents with calcific deposits $(2,36-39)$, some workers have suggested that factors other than sorption on calcium deposits are responsible for tissue concentration of these agents (15-19). The present and previous (38) analytical chemical studies, however, have demonstrated that selective in vivo concentration of ${ }^{99 \mathrm{~m}} \mathrm{Tc}-\mathrm{P}$ in altered soft tissues as well as bone is invariably associated with elevated tissue calcium content. These data are consistent with the conclusion that phenomena related to calcium accumulation are primarily responsible for in vivo concentration of ${ }^{99 \mathrm{~m} T \mathrm{~T}-\mathrm{P} \text { agents. }}$

In the case of acute myocardial infarction, our cell fractionation data are in agreement with previous 

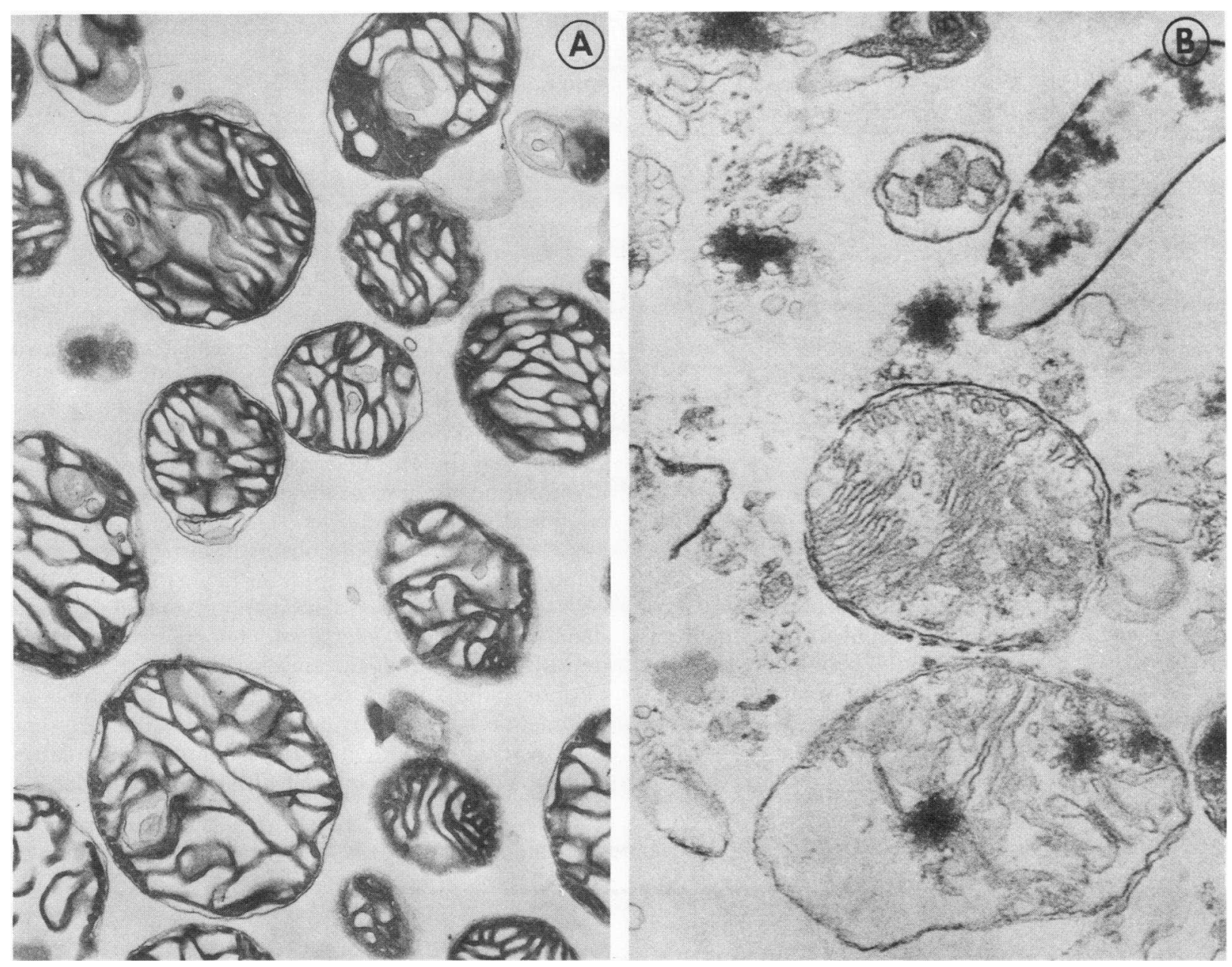

FIGURE 8 Ultrastructure of mitochondrial fractions. (A) Mitochondria from normal myocardium are well preserved and exhibit condensed configuration typical of normal isolated mitochondria. Double fixation in aldehyde and osmium, $\times 23,000$. (B) Mitochondrial fraction from infarcted myocardium contains some intact but swollen mitochondria as well as debris from disrupted mitochondria. Amorphous matrix densities are present, but calcific deposits are not observed. Compare with Fig. 4. Direct phosphate-buffered osmium fixation, $\times 42,200$.

TABLE IV

Normalized Levels of Technetium-99m Stannous Pyrophosphate and Iodine-131 Human Serum Albumin in Seven Dogs

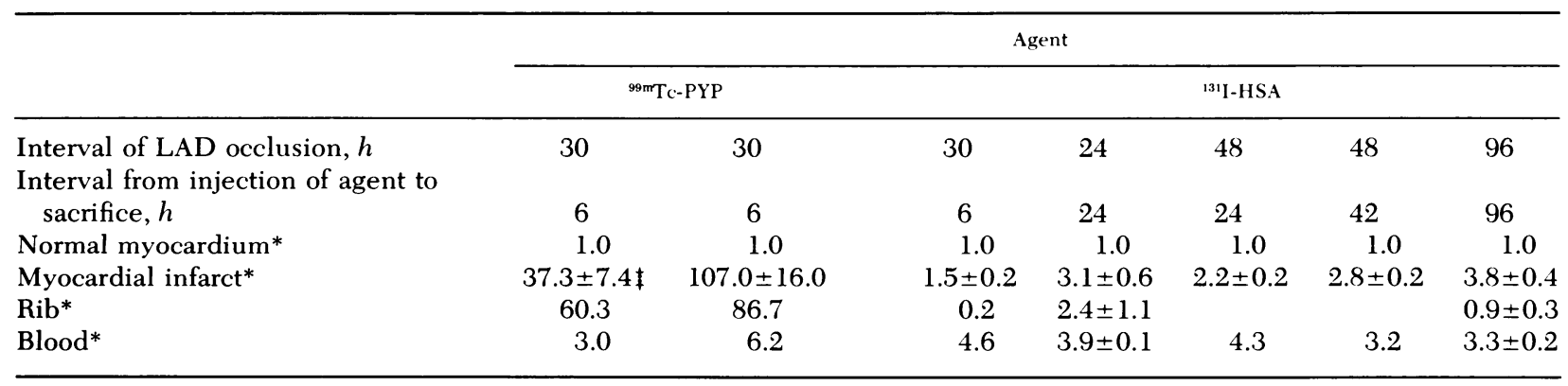

* Ratios of test samples to normal myocardium.

$\ddagger$ Data are given as mean $\pm \mathrm{SEM}$. 
TABLE V

Binding of Radiopharmaceuticals to Calcium Hydroxyapatite (HA) and Amorphous Calcium Phosphate (ACP) In Vitro

\begin{tabular}{|c|c|c|c|}
\hline Agent & $\begin{array}{l}\text { Protein } \\
\text { bound* }\end{array}$ & $\begin{array}{c}\text { Bound to } \\
\text { HA }\end{array}$ & $\begin{array}{c}\text { Bound to } \\
\text { ACP }\end{array}$ \\
\hline & & $\%$ & \\
\hline${ }^{99} \mathrm{TcO}_{4-}$ & - & $0.6 \pm 0.2 \ddagger$ & $1.7 \pm 0.2$ \\
\hline${ }^{99 m}$ Tc-PYP & - & $98.1 \pm 0.3$ & $94.9 \pm 0.2$ \\
\hline Serum ${ }^{99 m}$ Tc-PYP (5 min) & $51.0 \pm 9.0 \S$ & $84.6 \pm 2.2$ & 82.4 \\
\hline Serum ${ }^{99 m}$ Tc-PYP (30 min) & 48.2 & 68.7 & 67.3 \\
\hline Serum ${ }^{99 m}$ Tc-PYP (60 min) & $60.2 \pm 6.1$ & $67.1 \pm 5.5$ & $55.0 \pm 0.6$ \\
\hline Serum ${ }^{99 m}$ Tc-PYP (180 min) & 80.0 & 43.8 & \\
\hline Serum ${ }^{99 m}$ Tc-PYP (360 min) & 80.3 & 35.7 & \\
\hline
\end{tabular}

* 99mTc-PYP activity precipitated by $10 \%$ TCA.

† Data are given as mean \pm SEM.

$\$$ Measurements were made in duplicate or triplicate on sera from each of four dogs. Standard errors are reported when measurements from at least two dogs are grouped for a given time period.

studies which showed major localization of ${ }^{99 m} \mathrm{Tc}-\mathrm{P}$ in supernatant and other nonmitochondrial fractions (14-16). In the present study, however, electron microscopic examination showed that calcific deposits were not preserved in the mitochondrial fractions from infarcted myocardium. This observation suggests that fractionation of infarcted myocardium results in artifactual lowering of the calcium content of the mitochondrial fractions due to redistribution of calcium into other fractions. Our data as well as that of Dewanjee and Kahn $(15,16)$ also show that ${ }^{99 m}$ Tc-P and calcium share a similar distribution among the various fractions. The artifactually low ${ }^{99 \mathrm{~m}} \mathrm{Tc}-\mathrm{P}$ and calcium content of the mitochondrial fraction of infarcted myocardium likely results from a combination of solubilization of calcium deposits and rupture of calcified mitochondria during the isolation procedure. This conclusion is supported by the work of Jennings and Ganote who have emphasized that mitochondria from ischemic myocardium are exceedingly fragile (28).

Although cell fractionation data from infarcted myocardium must be interpreted with caution, the data do suggest that the elevated calcium content of infarcted myocardium is not exclusively localized to mitochondrial calcific deposits. This is consistent with our electron microscopic observations which showed some nonmitochondrial calcium deposition in muscle cells and which also demonstrated that only some damaged muscle cells had demonstrable calcific deposits. Nevertheless, muscle cells of the infarct periphery did show widespread hypercontraction and contraction band formation, phenomena that are typically associated with massive calcium accumulation with or without formation of ultrastructurally demon-

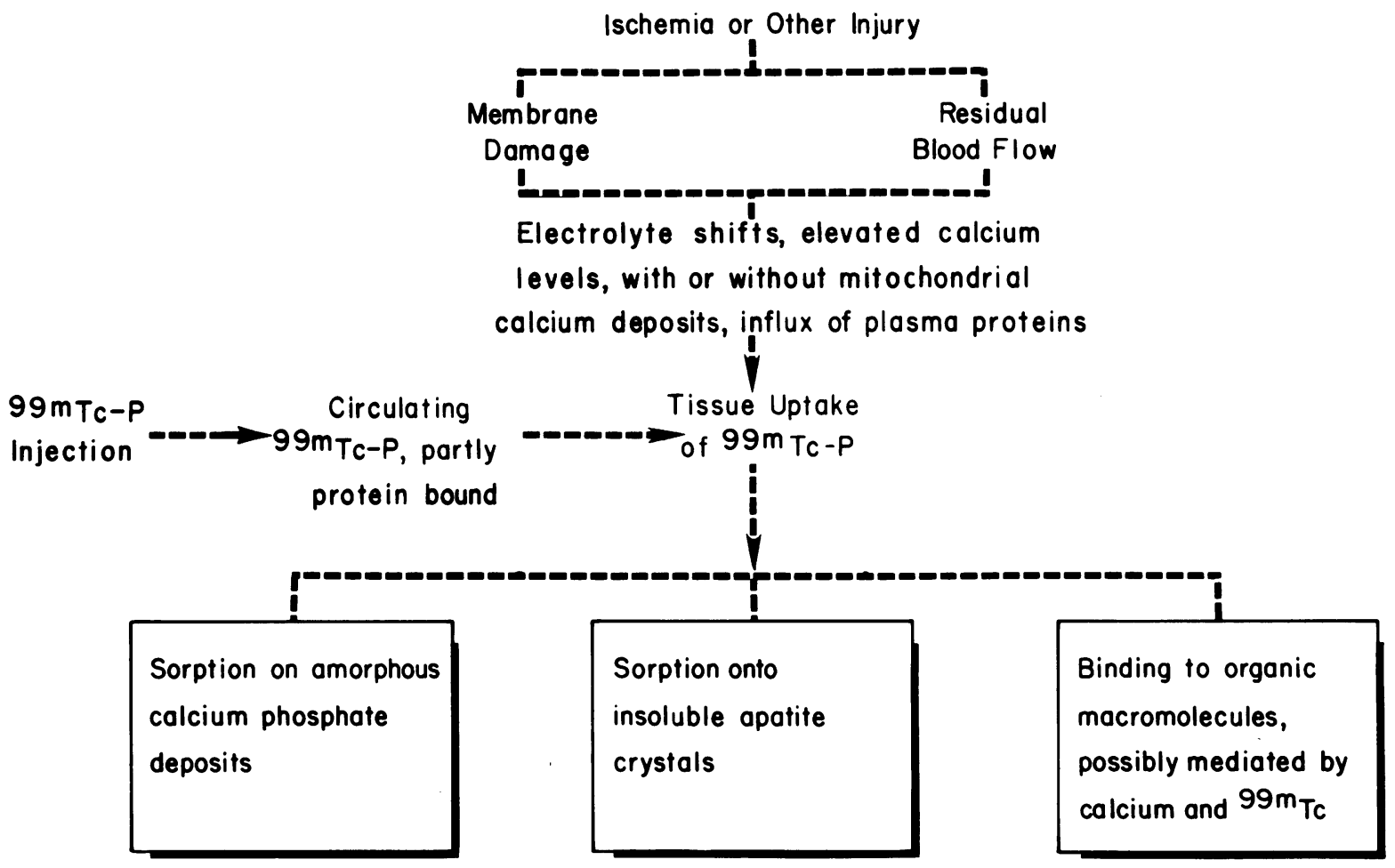

FIgure 9 Proposed pathophysiologic basis for the scintigraphic detection of tissue damage with ${ }^{99 \mathrm{~m} T c-P}$ radiopharmaceuticals. 
strable mitochondrial calcium deposits (3, 26-35). Damaged border zone myocardium with mildly elevated calcium levels and focal mitochondrial calcifica-

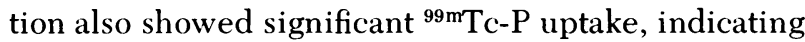
that massive calcium accumulation is not required for ${ }^{99 m} \mathrm{Tc}-\mathrm{P}$ concentration. These observations may be explained by variability in cellular response during the evolution of ischemic injury. After the onset of membrane damage in areas with significant blood flow, muscle cells become exposed to increased amounts of calcium derived from plasma (26-28, 33-35). This calcium may complex with myofibrils and other organic constituents of the cells (40). Plasma proteins also accumulate in severely damaged muscle cells $(31,41)$, and these proteins also may participate in calcium binding (42). Formation of ultrastructurally demonstrable mitochondrial calcific deposits apparently occurs only in cells which retain active mitochondrial function during a period of marked calcium influx $(26-28,43,44)$.

Our results showing lack of a linear relationship between ${ }^{99 \mathrm{~m}} \mathrm{Tc}-\mathrm{P}$ uptake and total tissue calcium concentration are consistent with available data regarding the interaction of ${ }^{99 \mathrm{~m}} \mathrm{Tc}-\mathrm{P}$ agents with various forms of tissue calcium stores. It is now appreciated that initial stages of calcium accumulation and calcification involve accumulation of calcium from plasma followed by precipitation of calcium phosphate in the form of amorphous (noncrystalline) and relatively soluble deposits with very high surface to volume ratio $(24,25,45)$. Subsequently, nonreversible hydrolysis of amorphous calcium phosphate results in the formation of insoluble, crystalline hydroxyapatite which undergoes progressive crystal growth into spicular deposits and progressive reduction in surface to volume ratio as the crystals enlarge (45). In biological calcification, the process appears to have an initial intracellular phase involving mitochondria with subsequent extracellular deposition of mineral $(43,45)$. In certain forms of pathological calcification, including calcification after acute myocardial ischemic injury, both amorphous (or microcrystalline) and crystalline calcific deposits can be found in mitochondria $(26-30)$, in association with calcium complexed to myofibrils and other organic macromolecules in the damaged cells, as described above. Conversion of amorphous calcium phosphate to hydroxyapatite in ischemically damaged tissues may be facilitated by low levels of ATP and magnesium $(46,47)$ and by a slightly alkaline $\mathrm{pH}$ in damaged regions receiving significant blood flow $(48,49)$. Pathological calcification also can result in deposition of unusual species of calcific material (50). Thus, calcification represents a dynamic process such that total calcium concentration reflects the sum total of constantly changing populations of calcium complexed with organic macromolecules, amorphous calcium phosphate deposits, and crystalline calcific material in different stages of growth.

Several studies have shown that the degree of phosphate and diphosphonate uptake for a given amount of calcific material is not constant but varies directly with the surface to volume ratio which in turn is dependent upon the stage of crystal growth $(38,39,45)$. Thus, calcific deposits in initial stages of formation have higher surface to volume ratio and higher sorption affinity for phosphate and diphosphonates than do fully mature hydroxyapatite crystals $(38,39,45)$. This is consistent with autoradiographic studies which have shown that radiopharmaceutical distribution in normal bone does not occur randomly but is selectively localized to regions of active calcification along the edges of bony trabeculae (39). Vascularity and local blood flow also influence the degree

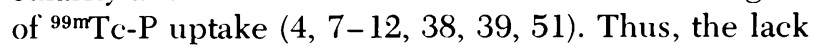
of a linear relationship between ${ }^{99 \mathrm{~m}} \mathrm{Tc}-\mathrm{P}$ and calcium levels appears to result mainly from local differences in blood flow as well as from the composition and physiochemical properties of tissue calcium stores.

It is also important to point out that any investigation of the relationship between ${ }^{99 \mathrm{~m} T \mathrm{~T}-\mathrm{P} \text { uptake and }}$ calcification must take into account differences in solubility of various calcium species. Amorphous calcium phosphate, the initial stage of tissue calcification, is much more soluble than crystalline hydroxyapatite (45) and may not be preserved in routinely prepared tissue sections $(52,53)$. In addition, radiographic visualization of calcification appears limited to foci of massive calcification containing abundant crystalline hydroxyapatite (38). Therefore, failure to detect calcification by routine histochemical or radiographic methods does not necessarily mean that ${ }^{99 \mathrm{~m}} \mathrm{Tc}-\mathrm{P}$ concentration in a given soft tissue lesion occurs in the absence of elevated tissue calcium content $(19,37,54)$.

Other theories regarding ${ }^{99 \mathrm{~m}} \mathrm{Tc}-\mathrm{P}$ uptake have proposed that high affinity binding of ${ }^{99 \mathrm{~m} T c-P}$ occurs on various organic substances, including organic matrix of bone (18), tissue phosphatases (19) and various proteins of damaged tissues $(15,16)$. Dewanjee and Kahn have proposed that concentration of ${ }^{99 \mathrm{~m} T c-P}$ in acute myocardial infarcts results primarily from polynuclear complexing with denatured proteins and other macromolecules $(15,16)$. This thesis was based on data suggesting that complexing of pyrophosphate with ${ }^{99 m} \mathrm{Tc}$ imparts an affinity for protein binding and results in higher infarct to normal ratios for ${ }^{99 \mathrm{~m} T c-P}$ than for free pyrophosphate $(15,16)$. In the present study, however, absolute levels of ${ }^{99 \mathrm{~m} T c-P Y P,}{ }^{99 \mathrm{~m} T c-E H D P}$ and ${ }^{3} \mathrm{H}-\mathrm{EHDP}$ in infarcted myocardium were found to be equivalent. In addition, Coleman et al. reported 
similar absolute concentration of ${ }^{32} \mathrm{P}$-pyrophosphate and ${ }^{99 m}$ Tc-PYP in infarcted myocardium (14).

The present and previous studies have shown that a significant fraction of circulating ${ }^{99 \mathrm{~m}} \mathrm{Tc}-\mathrm{P}$ is complexed to serum proteins $(15,16,36,55)$ and that serum proteins do deposit in damaged myocardium after development of defects in membrane integrity $(3,31,41)$. Nevertheless, the present study has shown that: $(a)$ intravenously injected ${ }^{131}$ I-HSA exhibits a significantly lower uptake rate and level of concentration in infarcted myocardium and bone compared to ${ }^{99 \mathrm{~m}} \mathrm{Tc}-\mathrm{P}$; (b) complexing of ${ }^{99 \mathrm{~m}} \mathrm{Tc}-\mathrm{P}$ with serum proteins results in only minimal reduction in the affinity of serum ${ }^{99 m} \mathrm{Tc}-\mathrm{P}$ activity for complexing with hydroxyapatite or freshly prepared amorphous calcium phosphate during the 1sth after injection of ${ }^{99 \mathrm{~m} T c-P}$; and $(c)$ significant reduction in calcium complexing affinity of ${ }^{99 m}$ Tc-P only occurs with circulation times of over $1 \mathrm{~h}$ when a large proportion of injected ${ }^{99 \mathrm{~m} T c-P}$ has cleared the circulation (55), suggesting that only a small fraction of injected ${ }^{99 \mathrm{~m} T c-P}$ has impaired calcium complexing affinity and delayed clearance from the circulation as a result of relatively tight binding to serum proteins. Since hydroxyapatite has a known affinity for protein binding $(56,57)$, some of the complexing of serum ${ }^{99 \mathrm{~m}} \mathrm{Tc}$-P with calcium may be mediated by adsorption of calcium with the protein moiety of protein-bound ${ }^{99 \mathrm{~m} T c-P}$; however, the data suggest that serum protein and ${ }^{99 m}$ Tc-P mainly undergo relatively loose coupling and that complexing of ${ }^{99 \mathrm{~m}} \mathrm{Tc}-\mathrm{P}$ with serum proteins primarily serves a carrier function.

The data reviewed above indicate that complexing of circulating ${ }^{99 \mathrm{~m}} \mathrm{Tc}-\mathrm{P}$ to serum proteins (and, probably, serum calcium) plays an insignificant role in subsequent tissue concentration of these agents. The available data, however, do suggest the possibility that uptake of ${ }^{99 m} \mathrm{Tc}-\mathrm{P}$ in damaged soft tissues may be partially mediated by complexing with denatured native proteins and other organic macromolecules as well as with serum proteins previously deposited in the damaged tissue. Dewanjee and Kahn have suggested that organic macromolecular complexing of ${ }^{99 m}$ Tc-P may be enhanced by an increased affinity of tissue macromolecules for ${ }^{99 \mathrm{~m}} \mathrm{Tc}-\mathrm{P}$ binding induced by changes in tertiary structure after tissue injury $(15,16)$. The data of Schelbert and associates (17) also can be interpreted as supporting the organic macromolecular complexing theory. Utilizing an in vitro fetal mouse heart organ culture system, these workers showed that ${ }^{99 \mathrm{~m} T \mathrm{~T}-\mathrm{PYP}}$ concentrated to a modest degree (2.8 times normal) in myocardium irreversibly injured by a combination of anoxia, substrate deprivation, and hyperthermia and that this modest uptake was not diminished when irreversible injury was produced in hearts cultivated in calcium-free medium (17). These observations, however, do not exclude the possi- bility that native stores of tissue calcium played a role in the uptake of ${ }^{99 \mathrm{~m}} \mathrm{Tc}-\mathrm{PYP}$ by fetal mouse myocardium.

Complexing of ${ }^{99 \mathrm{~m}} \mathrm{Tc}$ with tissue components has been suggested as a major factor in the concentration of other ${ }^{99 \mathrm{~m} T c}$ chelates as well as ${ }^{99 \mathrm{~m}} \mathrm{Tc}-\mathrm{P}$ agents in infarcted myocardium, possibly due to transchelation of the ${ }^{99 \mathrm{~m}} \mathrm{Tc}$ from the radiopharmaceuticals to damaged tissue constituents (58). In the case of ${ }^{203} \mathrm{Hg}$ organomercurials, the degree of concentration in damaged myocardium appears influenced both by the presence of mercury and by the nature of the organic molecule $(59,60)$. It is clear, however, that free pertechnetate does not concentrate significantly in damaged myocardium even though circulating pertechnetate is loosely bound to plasma proteins (61). Tissue calcium stores as well as the ${ }^{99 \mathrm{~m}} \mathrm{Tc}$ moiety of radiopharmaceuticals may play a role in organic macromolecular complexing of radiopharmaceuticals since the process of polynuclear complexing is facilitated by a variety of metal ions $(15,16)$. Further study appears warranted to elucidate the relationship between relative calcium complexing affinity of various radiopharmaceuticals and relative levels of concentration of these agents in damaged myocardium.

\section{ACKNOWLEDGMENTS}

The authors wish to acknowledge the excellent technical assistance of Ms. Anna Reynolds, Ms. Judy Ober, Ms. Janice McNatt, Mrs. Dorothy Gutekunst, Mrs. Katie Wolf, Mr. Gifford Ramsey, Mr. Curtis Garner, and Mr. Chuck Graham and the secretarial assistance of Miss Kathy Handrick, Mrs. Belina Lambert, and Mrs. Donna Place. The authors also are indebted to the Miami Valley Laboratories technical support groups and in particular to Mr. Gene Kinnett, Mr. Lionel McCreary, and Mr. Dave Hertmeyer.

This investigation was supported, in part, by National Institutes of Health Ischemic Heart Disease Specialized Center of Research grant HL 17669, grant HL 17777, and the Harry S. Moss Heart Fund.

\section{REFERENCES}

1. Willerson, J. T., R. W. Parkey, F. J. Bonte, S. L. Meyer, J. M. Atkins, and E. M. Stokely. 1975. Technetium stannous pyrophosphate myocardial scintigrams in patients with chest pain of varying etiology. Circulation. 51: 1046-1052.

2. Bonte, F. J., R. W. Parkey, K. D. Graham, J. Moore, and E. M. Stokely. 1974. A new method of radionuclide imaging of myocardial infarcts. Radiology. 110: 473-474.

3. Buja, L. M., R. W. Parkey, J. H. Dees, E. M. Stokely, R. A. Harris, Jr., F. J. Bonte, and J. T. Willerson. 1975. Morphologic correlates of technetium- $99 \mathrm{~m}$ stannous pyrophosphate imaging of acute myocardial infarcts in dogs. Circulation. 52: 596-607.

4. Buja, L. M., R. W. Parkey, E. M. Stokely, F. J. Bonte, and J. T. Willerson. 1976. Pathophysiology of technetium$99 \mathrm{~m}$ stannous pyrophosphate and thallium-201 scintigraphy of acute anterior myocardial infarcts in dogs. $J$. Clin. Invest. 57: 1508-1522. 
5. Lewis, M., L. M. Buja, S. Saffer, D. Mishelevich, E. M. Stokely, S. Lewis, R. W. Parkey, F. J. Bonte, and J. W. Willerson. 1977. Experimental infarct sizing utilizing computer processing and a three-dimensional model. Science (Wash. D. C.). 197: 167-169.

6. Pugh, B. R., L. M. Buja, R. W. Parkey, L. R. Poliner, F. J. Bonte, and J. T. Willerson. 1976. Cardioversion and "false positive" technetium-99m stannous pyrophosphate myocardial scintigrams. Circulation. 54: 399-403.

7. Botvinick, E. H., D. Shames, H. Lappin, J. V. Tyberg, R. Townsend, and W. W. Parmley. 1975. Noninvasive quantitation of myocardial infarction with technetium99m pyrophosphate. Circulation. 52: 909-915.

8. Zweiman, F. G., B. L. Holman, A. O'Keefe, and J. Idoine. 1975. Selective uptake of ${ }^{99 \mathrm{~m} T \mathrm{Tc}}$ complexes and ${ }^{67} \mathrm{Ga}$ in acutely infarcted myocardium. J. Nucl. Med. 16: 975-979.

9. Zaret, B. L., V. C. DiCola, R. K. Donabedian, S. Puri, S. Wolfson, G. S. Freedman, and L. S. Cohen. 1976. Dual radionuclide study of myocardial infarction. Relationship between myocardial uptake of potassium-43, technetium-99m stannous pyrophosphate, regional myocardial blood flow and creatine phosphokinase depletion. Circulation. 53: 422-428.

10. DiCola, V. C., G. S. Freedman, S. E. Downing, and B. L. Zaret. 1976. Myocardial uptake of technetium-99m stannous pyrophosphate following direct current transthoracic countershock. Circulation. 54: 980-986.

11. Bruno, F. P., F. R. Cobb, F. Rivas, and J. K. Goodrich. 1976. Evaluation of ${ }^{99 m}$ technetium stannous pyrophosphate as imaging agent in acute myocardial infarction. Circulation. 54: 71-78.

12. Marcus, M. L., R. J. Tomanek, J. C. Ehrhardt, R. E. Kerber, D. D. Brown, and F. M. Abboud. 1976. Relationships between myocardial perfusion, myocardial necrosis, and technetium-99m pyrophosphate uptake in dogs subjected to sudden coronary occlusion. Circulation. 54: 647-653.

13. Reimer, K. A., K. Martonffy, B. L. Schumacher, R. E. Henkin, J. L. Quinn, III, and R. B. Jennings. 1976. Cardiac localization of ${ }^{99 \mathrm{~m} T c-p y r o p h o s p h a t e}$ after temporary or permanent coronary occlusion in dogs. Am. J. Pathol. 82: 23A-24A. (Abstr.)

14. Coleman, R. E., M. S. Klein, S. A. Ahmed, E. S. Weiss, W. M. Buchholz, and B. E. Sobel. 1977. Mechanisms contributing to myocardial accumulation of technetium$99 \mathrm{~m}$ stannous pyrophosphate after coronary occlusion. Am. J. Cardiol. 39: 55-59.

15. Dewanjee, M. K., and P. C. Kahn. 1976. Mechanism of localization of $99 \mathrm{~m}$ Tc-labeled pyrophosphate and tetracycline in infarcted myocardium. J. Nucl. Med. 17: 639-646.

16. Dewanjee, M. K. 1976. Localization of skeletal-imaging ${ }^{99 \mathrm{~m}} \mathrm{Tc}$ chelates in dead cells in tissue culture: Concise communication. J. Nucl. Med. 17: 993-997.

17. Schelbert, H. R., J. S. Ingwall, H. W. Sybers, and W. L. Ashburn. 1976. Uptake of infarct-imaging agents in reversibly and irreversibly injured myocardium in cultured fetal mouse heart. Circ. Res. 39: 860-868.

18. Kaye, M., S. Silverton, and L. Rosenthall. 1975. ${ }^{99 \mathrm{~m} T \mathrm{~T}-}$ pyrophosphate: Studies in vivo and in vitro. $\mathrm{J} . \mathrm{Nucl}$. Med. 16: 40-45.

19. Zimmer, A. M., A. T. Isitman, and R. A. Holmes. 1975. Enzymatic inhibition of diphosphonate: A proposed mechanism of tissue uptake. J. Nucl. Med. 16: 352-356.

20. Baserga, R., and D. Malamud. 1969. Autoradiography. Techniques and Application. Hoeber Medical Division, Harper \& Row, Publishers, Inc., New York. 17-74.
21. John, M. K. 1972. Automated digestion system for safe use of perchloric acid. Anal. Chem. 44: 429-430.

22. Hogeboom, G. H. 1955. Fractionation of cell components of animal tissues. Methods Enzymol. 1: 16-19.

23. Lowry, O. H., N. J. Rosebrough, A. L. Farr, and R. J. Randall. 1951. Protein measurement with the Folin phenol reagent. J. Biol. Chem. 193: 265-275.

24. Francis, M. D., and N. C. Webb. 1971. Hydroxyapatite formation from a hydrated calcium monohydrogen phosphate precursor. Calcif. Tissue Res. 6: 335-342.

25. Termine, J. D., and E. D. Eanes. 1972. Comparative chemistry of amorphous and apatitic calcium phosphate preparations. Calcif. Tissue Res. 10: 171-197.

26. Shen, A. C., and R. B. Jennings. 1972. Myocardial calcium and magnesium in acute ischemic injury. Am. J. Pathol. 67: 417-440.

27. Kloner, R. A., C. E. Ganote, and R. B. Jennings. 1974. The "no-reflow" phenomenon after temporary coronary occlusion in the dog. J. Clin. Invest. 54: 1496-1508.

28. Jennings, R. B., and C. E. Ganote. 1976. Mitochondrial structure and function in acute myocardial ischemic injury. Circ. Res. 38(Suppl. I): I-80-I-91.

29. Buja, L. M., J. H. Dees, D. F. Harling, and J. T. Willerson. 1976. Analytical electron microscopic study of mitochondrial inclusions in canine myocardial infarcts. $J$. Histochem. Cytochem. 24: 508-516.

30. Hagler, H. K., K. P. Burton, R. H. Browne, R. C. Reynolds, G. H. Templeton, J. T. Willerson, and L. M. Buja. 1977. Energy dispersive X-ray spectroscopic (EDS) analysis of small particulate inclusions in hypoxic and ischemic myocardium. In Proceedings of the Illinois Institute of Technology Research Institute Scanning Electron Microscopy Symposium 1977. O. Johari, editor. Chicago Press Corporation, Chicago, Ill. 2: 145-152.

31. Buja, L. M., V. J. Ferrans, and R. G. Graw, Jr. 1976. Cardiac pathologic findings in patients treated with bone marrow transplantation. Hum. Pathol. 7: 17-45.

32. Buja, L. M., D. W. Bilheimer, R. W. Parkey, F. J. Bonte, and J. T. Willerson. 1977. Increased fatty acid uptake and abnormal lipid deposition: A characteristic feature of the peripheral and border zones of acute myocardial infarcts. Clin. Res. 25: 46A. (Abstr.)

33. Rona, G., M. Boutet, I. Hüttner, and H. Peters. 1973. Pathogenesis of isoproterenol-induced myocardial alterations: Functional and morphological correlates. Recent Adv. Stud. Card. Struct. Metab. 3: 507-525.

34. Fleckenstein, A., J. Janke, H. J. Döring, and O. Leder. 1974. Myocardial fiber necrosis due to intracellular $\mathrm{Ca}$ overload-a new principle in cardiac pathophysiology. Recent Adv. Stud. Card. Struct. Metab. 4: 563-580.

35. Wrogemann, K., and S. D. J. Pena. 1976. Mitochondrial calcium overload: A general mechanism for cell necrosis in muscle diseases. Lancet. I: 672-674.

36. Subramanian, G., J. G. McAfee, R. J. Blair, and F. D.

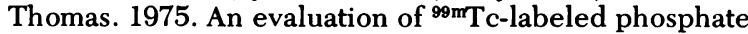
compounds as bone-imaging agents. In Radiopharmaceuticals. G. Subramanian, B. A. Rhodes, J. F. Cooper, and V. J. Sodd, editors. The Society of Nuclear Medicine, Inc., New York. 319-328.

37. Merrick, M. V. 1975. Review article-bone scanning. $\mathrm{Br}$. J. Radiol. 48: 327-351.

38. Francis, M. D., C. L. Slough, A. J. Tofe, and E. B. Silberstein. 1976. Factors affecting uptake and retention of Tc-99m-diphosphate and Tc-99m-pertechnetate in osseous, connective and soft tissue. Calcif. Tissue Res. 20: $303-311$.

39. Jones, A. G., M. D. Francis, and M. A. Davis. 1976. 
Bone scanning: Radionuclidic reaction mechanisms. Semin. Nucl. Med. 6: 3-18.

40. Katz, A. M., and D. I. Repke. 1973. Calcium-membrane interactions in the myocardium: Effects of ouabain, epinephrine and $3^{\prime}, 5^{\prime}$-cyclic adenosine monophosphate. Am. J. Cardiol. 31: 193-201.

41. Kent, S. P. 1966. Intracellular plasma protein: A manifestation of cell injury in myocardial ischemia. Nature (Lond.). 210: 1279-1281.

42. McLean, F. C., and A. B. Hastings. 1935. Clinical estimation and significance of calcium-ion concentrations in the blood. Am. J. Med. Sci. 189: 601-613.

43. Lehninger, A. L. 1970. Mitochondria and calcium ion transport. Biochem. J. 119: 129-138.

44. Carafoli, E., and M. Crompton. 1976. Calcium ions and mitochondria. Symp. Soc. Exp. Biol. 30: 89-115.

45. Posner, A. S. 1969. Crystal chemistry of bone mineral. Physiol. Rev. 49: 760-792.

46. Boskey, A. L., and A. S. Posner. 1974. Magnesium stabilization of amorphous calcium phosphate: A kinetic study. Mater. Res. Bull. 9: 907-916.

47. Blumenthal, W. C., F. Betts, and A. S. Posner. 1975. Nucleotide stabilization of amorphous calcium phosphate. Mater. Res. Bull. 10: 1055-1060.

48. Krug, A. 1970. The extent of ischemic damage in the myocardium of the cat after permanent and temporary coronary occlusion. J. Thorac. Cardiovasc. Surg. 60: $242-247$

49. Krug, A. 1975. Alterations in myocardial hydrogen ion concentration after temporary coronary occlusion: A sign of irreversible cell damage. Am. J. Cardiol. 36: 214-217.

50. Alfrey, A. C., C. C. Solomons, J. Ciricillo, and N. L. Miller. 1976. Extraosseous calcification. Evidence for abnormal pyrophosphate metabolism in uremia. J. Clin. Invest. 57: 692-699.
51. Genant, H. K., G. J. Bautovich, M. Singh, K. A. Lathrop, and P. V. Harper. 1974. Bone-seeking radionuclides: An in vivo study of factors affecting skeletal uptake. Radiology. 113: 373-382.

52. Ranaud, S. 1959. Superiority of alcoholic over aqueous fixation in the histochemical detection of calcium. Stain Technol. 34: 267-271.

53. Meloan, S. N., H. Puchtler, and L. S. Valentine. 1972. Alkaline and acid alizarin red $\mathrm{S}$ stains for alkali-soluble and alkali-insoluble calcium deposits. Arch. Pathol. 93: $190-197$.

54. Lowenthal, I. S., D. E. Tow, and Y. C. Chang. 1975. Accumulation of ${ }^{99 \mathrm{~m}} \mathrm{Tc}$-polyphosphate in two squamous cell carcinomas of the lung. Case report. J. Nucl. Med. 16: $1021-1023$.

55. Krishnamurthy, G. T., R. J. Huebotter, C. F. Walsh, J. R. Taylor, M. D. Kehr, M. Tubis, and W. H. Blahd. 1975. Kinetics of ${ }^{99 \mathrm{~m} T c-l a b e l e d}$ pyrophosphate and polyphosphate in man. J. Nucl. Med. 16: 109-115.

56. Tiselius, A., S. Hjertén, and Ö. Levin. 1956. Protein chromatography on calcium phosphate columns. Arch. Biochem. Biophys. 65: 132-155.

57. Bernardi, G. 1971. Chromatography of proteins on hydroxyapatite. Methods Enzymol. 21: 325-339.

58. Poe, N. D. 1977. Rationale and radiopharmaceuticals for myocardial imaging. Semin. Nucl. Med. 7: 7-14.

59. Davis, M. A., B. L. Holman, and A. N. Carmel. 1976. Evaluation of radiopharmaceuticals sequestered by acutely damaged myocardium.J. Nucl. Med. 17: 911-917.

60. Holman, B. L., M. A. Davis, and R. N. Hanson. 1977. Myocardial infarct imaging with technetium-labeled complexes. Semin. Nucl. Med. 7: 29-35.

61. Hays, M. T., and F. A. Green. 1973. In vitro studies of ${ }^{99 \mathrm{~m}} \mathrm{Tc}$-pertechnetate binding by human serum and tissue. J. Nucl. Med. 14: 149-158. 